Article

\title{
Au-Ag-S-Se-Cl-Br Mineralization at the Corrida Deposit (Russia) and Physicochemical Conditions of Ore Formation
}

\author{
Elena E. Kolova ${ }^{1}$ D, Nataly E. Savva ${ }^{1}$, Tatiana V. Zhuravkova ${ }^{2,3}$, Anton N. Glukhov ${ }^{1}$ and \\ Galina A. Palyanova 2,3,*(D) \\ 1 Shilo North-East Interdisciplinary Scientific Research Institute, \\ Far Eastern Branch of the Russian Academy of Sciences, 16 Portovaya St., 685000 Magadan, Russia; \\ kolova@neisri.ru (E.E.K.); savva@neisri.ru (N.E.S.); gluhov76@list.ru (A.N.G.) \\ 2 Sobolev Institute of Geology and Mineralogy, Siberian Branch of Russian Academy of Sciences, \\ 3 Koptyuga Ave., 630090 Novosibirsk, Russia; zhur0502@rambler.ru \\ 3 Department of Geology and Geophysics, Novosibirsk State University, 1 Pirogova St., \\ 630090 Novosibirsk, Russia \\ * Correspondence: palyan@igm.nsc.ru
}

check for updates

Citation: Kolova, E.E.; Savva, N.E.; Zhuravkova, T.V.; Glukhov, A.N.; Palyanova, G.A. Au-Ag-S-Se-Cl-Br Mineralization at the Corrida Deposit (Russia) and Physicochemical Conditions of Ore Formation. Minerals 2021, 11, 144. https:// doi.org/10.3390/min11020144

Academic Editor: Stefano Salvi

Received: 29 November 2020

Accepted: 26 January 2021

Published: 30 January 2021

Publisher's Note: MDPI stays neutral with regard to jurisdictional claims in published maps and institutional affiliations.

Copyright: (c) 2021 by the authors. Licensee MDPI, Basel, Switzerland. This article is an open access article distributed under the terms and conditions of the Creative Commons Attribution (CC BY) license (https:// creativecommons.org/licenses/by/ $4.0 /)$.

\begin{abstract}
The mineral and chemical compositions of ores from the Corrida epithermal Au-Ag deposit (Chukchi Peninsula, Russia) were studied using the optical and scanning electron microscopy with X-ray energy-dispersion microanalysis. The deposit was formed at the time close to the period when the basic volume of acid magmas had been emplaced within the Okhotsk-Chukotka belt ( 84 to $80 \mathrm{Ma}$ ). The Au-Ag mineralization is distinguished with Au-Ag sulphides and selenides (uytenbogaardtite-fischesserite solid solution, Se-acanthite, S-naumannite) and Ag halides of the chlorargyrite-embolite-bromargyrite series. The ores were formed in two stages. Using microthermometric methods, it has been established that the ore-bearing quartz was formed in the mediumtemperature environment $\left(340-160{ }^{\circ} \mathrm{C}\right.$ ) with the participation of low-salt (3.55 to $0.18 \mathrm{wt} . \% \mathrm{NaCl}$ eq.) hydrotherms, mostly of the $\mathrm{NaCl}$ composition with magnesium, iron and low-density $\mathrm{CO}_{2}$. According to our results of thermodynamic modeling at temperatures from 300 to $25^{\circ} \mathrm{C}$ and data on mineral metasomatic alterations of the host rocks, the Au-Ag-S-Se-Cl-Br mineralization was formed at decreasing temperature and fugacity of sulphur $\left(\log f S_{2}\right.$ from -6 to -27$)$, selenium $\left(\log f \mathrm{Se}_{2}\right.$ from -14 to -35$)$, and oxygen $\left(\log f \mathrm{O}_{2}\right.$ from -36 to -62$)$, with near-neutral solutions replaced by acid solutions. Analysis of the obtained data shows that the Corrida refers to the group of the LS-type epithermal deposits. This deposit is a new example of epithermal deposits with significant quantities of $\mathrm{Au}-\mathrm{Ag}$ chalcogenides (acanthite, uytenbogaardtite, fischesserite, naumannite and others).
\end{abstract}

Keywords: Arctic; epithermal mineralization; Corrida deposit (Chukchi Peninsula, Russia); LS-type of deposits; Au-Ag-S-Se-Cl-Br mineralization; physicochemical parameters of ore formation ( $\mathrm{T}, \mathrm{P}$, $\left.f \mathrm{O}_{2}, f \mathrm{~S}_{2}, f \mathrm{Se}_{2}, \mathrm{pH}\right)$

\section{Introduction}

The exploitation of the Northern Sea Route and technological solutions of arranging production in the severe climatic conditions make the Arctic part of Eurasia increasingly interesting for investors [1]. Over the last 20 years, in Central and West Chukotka, more than 10 epithermal gold deposits have been explored and involved in mining production, though in the second half of the 20th century they were considered unfeasible. The resource base re-evaluation, which led to the successful exploration of mining objects, was based on their comprehensive study [2-7] and on the accumulated world insight into epithermal mineralization [8-13]. The Chukchi Peninsula is located to the east of the $180^{\circ}$ meridian (Figure 1). For some primarily infrastructure reasons, manifestations of different ore types, including epithermal Au-Ag ones, known ever since the 1970s, have so far been 
insufficiently studied. Some practical and research works generally characterize only their geological structure and the morphology of ore bodies exposed on the surface $[14,15]$.

The accumulated data on the epithermal $\mathrm{Au}-\mathrm{Ag}$ deposits illustrate that they are formed in the areas of calc-alcaline volcanism associated with convergent tectonic regimes, at the depth of no more than $2 \mathrm{~km}$ from the surface and temperatures from 300 to $100{ }^{\circ} \mathrm{C}$, from low-salt hydrothermal fluids $[11,12,16]$. Depending on the chemical compositions and acidity of ore-forming solutions, and the degree of their interaction with host rocks, the fugacities of sulphur and oxygen [10,17-19], T, and P-parameters of the ore-formation process, three contrasting types of $\mathrm{Au}-\mathrm{Ag}$ mineralization are formed at different levels of the ore system. High-sulphidation (HS), intermediate-sulphidation (IS), and low-sulphidation (LS) types differ in mineral compositions, ore textures, geochemistry, hydrothermal-metasomatic alterations, and ore potentials for depth $[9-13,16]$. Examples of HS deposits include Lepanto (Philippines), Summitville (CO, USA) [13,20]; IS depositsSilbak-Premier (British Columbia) [13]; LS deposits—Creede (CO, USA), Hishikari (Japan), and Apacheta (Peru) [13,21,22].

In 2013, E.E. Kolova participated in prospecting works arranged by a private geological company in East Chukotka. The greatest attention was drawn to the Corrida deposit (145 km to the east of the settlement of Egvekinot, in the Erguveyem River basin), discovered by geologists V.I. Plyasunov and G.A. Tynankergav in 1975.

The aim of this study is to investigate the features of Au-Ag-S-Se-Cl-Br mineralization at the epithermal Au-Ag Corrida deposit (Chukchi Peninsula, Russia) and to estimate the physicochemical conditions of its formation based on the fluid inclusions study and thermodynamic modeling.

\section{Geological Situation}

The Corrida deposit is located in the central part of the East-Chukotka flank zone of the Okhotsk-Chukotka volcanic belt (OCVB). It is the largest province of the Cretaceous calc-alkaline magmatism, localized at the joint of the North-Asian continent and the North Pacific, where it forms a marginal continental Andean-type belt [23]. The deposit was discovered by 1:50,000-scale geologic mapping in the Soviet-period [24].

The Corrida deposit belongs to the Erguveyem ore district [15], confined to the similarly named volcanic-tectonic structure of circular type, which is $90 \mathrm{~km}$ in diameter. It is built from periclinally deposited Late Cretaceous volcanites of the calc-alkaline series $\left(\mathrm{Na}_{2} \mathrm{O} / \mathrm{K}_{2} \mathrm{O}\right.$ ratio ranges between 1.5 and 5.6) [24]; among these, the Nyrvakinot Formation, composed of andesites (U-Pb zircon age ca. 88.1 Ma) and felsic volcanites of the Amgen' Formations (U-Pb zircon age ca. $84-80 \mathrm{Ma}$ ) prevail [23,25]. The stock (Figure 1) exposed in the central part of the volcanic structure is about $15 \mathrm{~km}$ in diameter, built from quartz syenites and monzonites of the Late Cretaceous Ekityn complex of the estimated age U-Pb $84 \pm 1.2 \mathrm{Ma}\left(\mathrm{Na}_{2} \mathrm{O} / \mathrm{K}_{2} \mathrm{O}\right.$ ratio ranges between 0.5 and 3.0) [24]. Small intrusions and dykes of granites, granodiorites, monzonites, syenites, subvolcanic bodies of fluidal and spherolite rhyolites and andesites of the Early and Late Cretaceous age are widely spread [24]. The structure basement is composed of Late Triassic to Early Cretaceous volcanic-terrigenous-siliceous masses and associated gabbroids and ophiolites of the Velmay island-arc terrane [26]; their debris is observed in coarsely fragmented tuffs in the basement of the Amgen' rocks [27]. All known occurrences in the Erguveyem ore district are located at the joints of circular fractures bounding the volcanic-tectonic structure with regional faults of the north-north-eastern strike. 

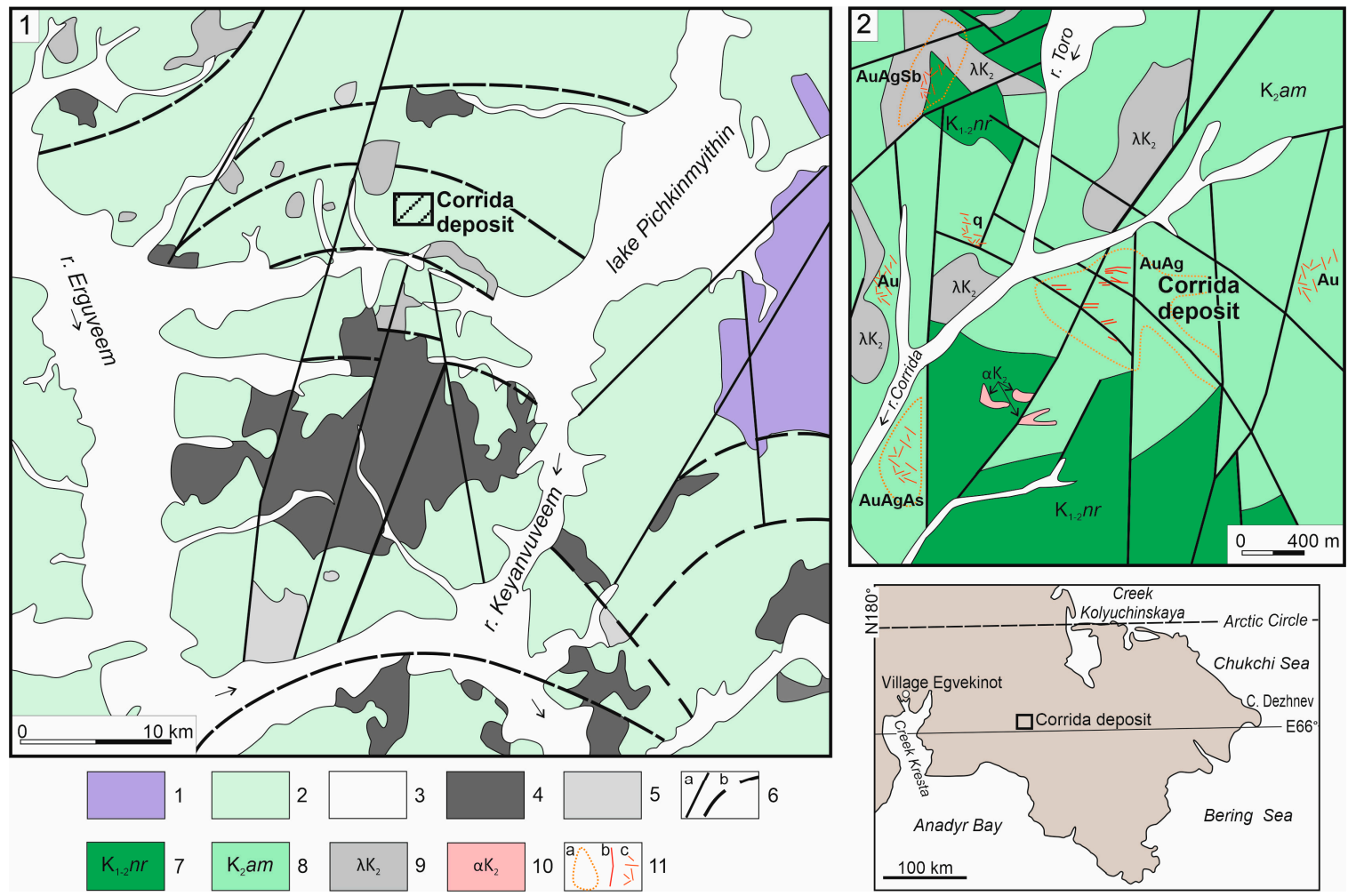

Figure 1. Geological map of the Erguveyem ore district (1) and the Corrida ore field (2) [24,26]. 1-6-illustration (1): 1-Late Triassic-Early Cretaceous volcanogenic-terrigenous-siliceous formation; 2-Cretaceous volcanic rocks; 3-Quaternary aqueoglacial and alluvial formations, with the main water flow directions; 4-Late Cretaceous granitoids; 5-Late Cretaceous subvolcanic rhyolite and andesite bodies; 6-tectonic dislocations: a-faults; b-dislocations of volcanic-tectonic structures; 7-11-illustration (2): 7-volcanic rocks of the Nyrvakinot Formation; 8-volcanic rocks of the Amgen' Formation; 9, 10-Late Cretaceous subvolcanic bodies: 9-rhyolite; 10-andesite; 11—ore features: a-hydrothermal-metasomatic alteration zones; $b$-lodes; $c$ —stockwork veinlet zones.

In the ore field of the Corrida deposit, the Nyrvakinot Formation is overlapped by acid effusives of the Amgen' Formation (Figure 1). The latter contains three benches. The first includes multicolored lapilli, and, more seldom, agglomerate tuffs of rhyolites and rhyodacites with lenses of tuff conglomerates with a lot of coarsely fragmented pyroclastic material and basement rock fragments. The second is composed of vitric tuffs of rhyolites and rhyodacites, with fragments of feldspar, quartz, and glass crystals prevailing in their composition. The third consists of rhyolite ignimbrites with rare interbeds of vitric tuffs and dacites [28]. On watershed tops, rare isolated stacks built from cenotypal andesibasalts of the Nulingran Formation are found. Volcanites are broken by extrusions, subvolcanic bodies and dykes of andesites, basalts, massive and fluidal rhyolites.

The most intense alterations with clear vertical zoning are observed in the felsic tuffs of the Amgen' Formation. Coarse-grained tuffs with sericite and sericite-quartz alterations, with adularia-quartz veining including $\mathrm{Au}-\mathrm{Ag}$ mineralization, occur within the elevation interval of $200-350 \mathrm{~m}$. At 350-400 m, we observe intense argillic alteration and hematitization. Within $400-450 \mathrm{~m}$, there are kaolinite-alunite-quartz advanced argillic alterations ("secondary quartzites" by Russian therminology) that host rare quartz veinlets with poor sulphide mineralization. Within the interval of 450-500 m, welded ash tuffs are weakly altered. The unaltered ignimbrites occur above $500 \mathrm{~m}$.

The ore bodies present the adularia-quartz veining zones with rare thin $(0.1-0.5 \mathrm{~m})$ veins. The bodies have mostly northwestern and northeastern strike, north and north-east dip (50-60 ) and extremely uneven thickness, from 5 to $15 \mathrm{~m}$, with swells of up to $35 \mathrm{~m}$. Along the strike, they are traced from the surface for $1.3 \mathrm{~km}$. From data [24], it can be seen that gold grade in ores varies from 1 to $33 \mathrm{ppm}$, and silver grade from 116 to $622 \mathrm{ppm}$. 
Veins and veinlets are built mostly from medium-, fine-grained, cryptocrystalline chalcedonic quartz, seldom associated with adularia. They often have colloform-banded, framboidal-platy, massive, porous, brecciform, and breccia structures, and seldom have drusy structures (Figure 2). In breccia aggregates, numerous rubbles are presented by host rocks (Figure 2) cemented by cryptocrystalline quartz. The ore mineralization is disseminated unevenly from fine and uniform to sporadic and nested.
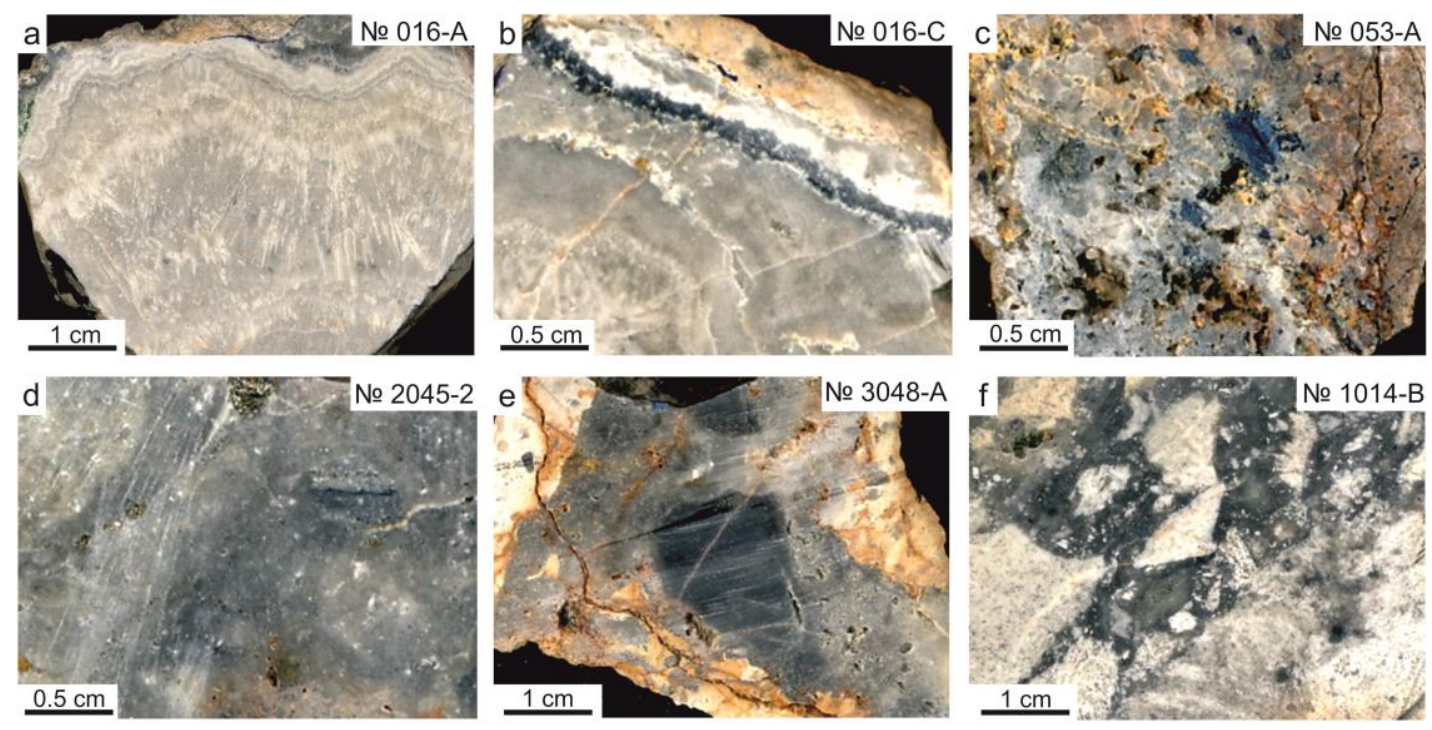

Figure 2. Typical textures of Corrida ores: (a)—combination of crustify-platy and colloform-banded; (b)—banded; (c)—massive; (d)—fragmentally brecciform; (e)—porous; (f) - breccia (fragments of monoquartzites in cryptocrystalline quartz).

\section{Materials and Methods}

The ore has been studied in polished sections under the AXIOPLAN Imagin microscope.( NEISRI FEB RAS, Magadan, Russia) The chemical compositions of the minerals were determined with the Camebax X-ray electron-probe microanalyzer (FEB RAS, Magadan, Russia) (analyst E.M. Goryacheva) (EDS) and QEMSCAN attached to the EVO50 scanning electron microscope (FEB RAS, Magadan, Russia) (SEM) with the Quantax Esprit system of X-ray energy-dispersion microanalysis system using the standard P/B-ZAF method (analyst T.V. Subbotnikova). The content range was $0.0 \mathrm{n}-100 \%$ with an error for the main components not exceeding $1 \mathrm{wt} . \%$. Statistic calculations of native gold grades were made with the GOLD software (IVerison) developed by S.V. Preis.

Additional analyses of composition of sphalerite and associated minerals were carried out using a MIRA 3 LMU (Tescan Orsay Holding, Novosibirsk, Russia) with EDS INCA Energy 450+ (Analytical Center for Multi-elemental and Isotope Research, Siberian Branch, Russian Academy of Sciences, Novosibirsk, Russia, analyst N.S. Karmanov). The operation conditions were: an accelerating voltage of $20 \mathrm{kV}$, a probe current of $1 \mathrm{nA}$ and a spectrum recording time of $20 \mathrm{~s}$. The detection limits of elements were $<0.1 \%$. The uncertainty was $\leq 1 \%$ for major components ( $>10-15 \mathrm{wt} . \%$ ) and $<2 \%$ for minor ones (1-10 wt. $\%$ ). These dates were used for thermodynamic modeling.

Microthermometry of fluid inclusions was conducted in NEISRI FEB RAS with the measuring set based on the THMSG-600 stage (made by Linkam, London, UK), Motic microscope, Moticam camcorder, Olympus x 50 long-focus lens, and the control computer. Individual fluid inclusions (FI) were studied following the methodologies from [29,30]. The fill factor $(\mathrm{FF})$ was calculated considering FI, flattened in shape, by the formula: $\mathrm{FF}=\mathrm{Sf} \div \mathrm{Sv} \times 100$, where Sf stands for the area of the fluid phase, and Sv, for that of the vacuole. The salt composition of solutions was determined by eutectic temperatures [31]; salt concentration, by the ice melting temperature $\left(\mathrm{T}_{\text {ice. mel. }}\right)$, according to [32]. Salt concen- 
trations as well as water vapor density and pressures were calculated using the FLINCOR software [33] according to the system outlined in [34]. Compositions of gas mixtures $\left(\mathrm{CO}_{2}\right.$, $\mathrm{N}_{2}, \mathrm{CH}_{4}$ ) in fluid inclusions were determined by Raman analyses on the Lab Ram HR 800 Raman dispersion spectrometer in the wide spectrum range of $150-3800 \mathrm{~cm}^{-1}$, with the exciting line $532 \mathrm{~nm}$ of the He-Ne laser and the spectral slit $1.8 \mathrm{~cm}^{-1}$. Complex contours were disintegrated with the Origin 7.5 software. Raman-spectroscopy was carried out at the Analytical Center for Multielemental and Isotope Research, Siberian Branch, Russian Academy of Sciences, Novosibirsk, Russia.

$\log f \mathrm{~S}_{2}-\left(\log f \mathrm{Se}_{2}, \log f \mathrm{O}_{2}\right)$ and $\log f \mathrm{O}_{2}-\mathrm{pH}$ diagrams at $25-300{ }^{\circ} \mathrm{C}$ were calculated by the method suggested by Garrels and Christ [35]. Gibbs free energies $\left(G_{T}\right)$ used in calculating chemical equations, involving $\mathrm{Fe}, \mathrm{Cu}, \mathrm{Zn}$, and $\mathrm{Pb}$ minerals, were taken from the databases of the Selector software package for Windows [36]: for sulphides and oxides-s_sprons07.DB [37]; for selenides and sulphates—s_Yokokawa.DB [38]. Thermodynamic constants for iron sulphides were taken from the Thermodem database [39]; for arsenopyrite and loellingite, from [40]; for arsenic, from [41]. Calculations $\mathrm{G}_{\mathrm{T}}$ for $\mathrm{Au}-\mathrm{Ag}$ minerals involve the thermodynamic data from [42-44]. Thermodynamic properties for Ag chlorides and bromides were taken from [45,46]. Sulphur fugacity $\left(f S_{2}\right)$ and temperatures of mineral formation were estimated using the electrum-sphalerite geothermometer based on the data on Fe-content of sphalerite $\left(\mathrm{x}_{\mathrm{FeS}}\right)$ and the amount of $\mathrm{Ag}\left(\mathrm{x}_{\mathrm{Ag}}\right)$ in the coexisting native gold $\left(\mathrm{Au}_{1-x} \mathrm{Ag}_{\mathrm{x}}\right)$. Calculations were performed using the related equations from $[17,47]$.

\section{Results}

\subsection{Mineral Composition of Ores}

The present research has established over 20 ore and 11 vein minerals at the Corrida deposit (Table 1).

Table 1. Mineral composition of Corrida ores.

\begin{tabular}{|c|c|c|c|}
\hline Groups & Basic & Secondary & Rare \\
\hline Vein & Quartz & $\begin{array}{l}\text { Adularia } \\
\text { Albite } \\
\text { Hydromica } \\
\text { Kaolinite } \\
\text { Jarosite }\end{array}$ & $\begin{array}{l}\text { Carbonate } \\
\text { Zeolite } \\
\text { Epidote } \\
\text { Actinolite }\end{array}$ \\
\hline Ore & $\begin{array}{c}\text { Pyrite } \\
\text { Galena } \\
\text { Acanthite * } \\
\text { Naumannite * }\end{array}$ & $\begin{array}{c}\text { Sphalerite } \\
\text { Arsenopyrite } \\
\text { Native gold * } \\
\text { Chalcopyrite } \\
\text { Fahlores } \\
\text { Bromargyrite* } \\
\text { Au-chlorargyrite * }\end{array}$ & $\begin{array}{l}\text { Argyrodite * } \\
\text { Polybasite* } \\
\text { Pyrargyrite* } \\
\text { Miargyrite * } \\
\text { Clausthalite * } \\
\text { Andorite } \\
\text { Lenaite * } \\
\text { Sternbergite * } \\
\text { Argentopyrite * } \\
\text { Uytenbogaardtite * } \\
\text { Fischesserite* } \\
\text { Native silver }\end{array}$ \\
\hline Hypergene & $\begin{array}{l}\text { Limonite } \\
\text { Chalcocite }\end{array}$ & Anglesite & $\begin{array}{c}\text { Chlorargyrite * } \\
\text { Acanthite }\end{array}$ \\
\hline
\end{tabular}

* Chemical compositions of minerals are presented in Tables 2 and 3. 
Table 2. Compositions of sulphides (below, and in Tables 3-5, the analyses are not $100 \%$ standardized).

\begin{tabular}{|c|c|c|c|c|c|c|}
\hline \multirow{2}{*}{ Mineral } & \multicolumn{5}{|c|}{ Element Concentrations, wt.\% } & \multirow{2}{*}{ Sum } \\
\hline & Ag & Zn & As & $\mathrm{Fe}$ & $\mathbf{S}$ & \\
\hline \multirow{4}{*}{ Pyrite } & & & & 45.55 & 54.45 & 100.00 \\
\hline & & & & 46.45 & 53.55 & 100.00 \\
\hline & & & & 47.84 & 52.16 & 100.00 \\
\hline & & & & 48.37 & 51.63 & 100.00 \\
\hline Arsenopyrite & & & 43.75 & 37.44 & 18.80 & 100.00 \\
\hline \multirow{6}{*}{ Sphalerite } & 4.66 & 55.66 & & 5.96 & 33.72 & 100.00 \\
\hline & 2.45 & 61.97 & & 4.45 & 31.02 & 100.00 \\
\hline & 3.50 & 62.07 & & 1.53 & 32.89 & 100.00 \\
\hline & & 62.95 & & 1.98 & 35.07 & 100.00 \\
\hline & 1.68 & 63.30 & 1.03 & & 33.60 & 99.95 \\
\hline & & 65.09 & 2.25 & & 32.67 & 100.00 \\
\hline
\end{tabular}

Table 3. Compositions of clausthalite and minerals of Au and Ag.

\begin{tabular}{|c|c|c|c|c|c|c|c|c|c|c|c|}
\hline \multirow{2}{*}{ Mineral } & \multicolumn{10}{|c|}{ Element Concentrations, wt.\% } & \multirow[t]{2}{*}{ Sum } \\
\hline & $\mathrm{Fe}$ & $\mathrm{Pb}$ & Zn & $\mathrm{Ge}$ & $\mathrm{Cu}$ & $\mathrm{Au}$ & Ag & $\mathrm{Sb}$ & Se & $\mathrm{S}$ & \\
\hline \multirow{2}{*}{ Clausthalite } & & 72.02 & & & & & & & 27.90 & & 99.92 \\
\hline & & 72.54 & & & & & & & 26.99 & & 99.53 \\
\hline \multirow{5}{*}{ Naumannite } & & & & & & & 72.76 & & 27.24 & & 100.00 \\
\hline & & & & & & & 73.36 & & 25.60 & 1.04 & 100.00 \\
\hline & & & & & & & 74.51 & & 24.50 & 0.98 & 100.00 \\
\hline & & & & & & & 76.29 & & 21.49 & 2.22 & 100.00 \\
\hline & & & & & & & 77.75 & & 19.26 & 2.98 & 100.00 \\
\hline \multirow{2}{*}{$\begin{array}{l}\text { Uytenbogaardtite- } \\
\text { fischesserite }\end{array}$} & & & & & & 3.00 & 76.34 & & 18.36 & 2.30 & 100.00 \\
\hline & & & & & & 13.78 & 77.73 & & & 7.15 & 100.00 \\
\hline \multirow{3}{*}{ Argyrodite } & & & & 4.97 & & & 72.69 & & 13.25 & 9.09 & 100.00 \\
\hline & & & & 5.53 & & & 72.57 & & 10.74 & 11.17 & 100.00 \\
\hline & & & & 5.94 & & & 69.90 & & 10.60 & 10.43 & 98.87 \\
\hline \multirow[b]{2}{*}{ Andorite } & & 13.22 & & & & & 22.72 & 18.31 & 3.70 & 11.40 & 99.61 \\
\hline & & 18.52 & & & & & 17.22 & 22.17 & 1.81 & 22.62 & 98.40 \\
\hline Pyrargyrite & & & & & & & 59.70 & 20.58 & 3.43 & 14.33 & 98.04 \\
\hline \multirow{3}{*}{ Miargyrite } & & & & & & & 45.99 & 41.19 & 4.55 & 8.28 & 100.00 \\
\hline & & & & & & & 35.02 & 40.35 & 1.80 & 22.00 & 100.97 \\
\hline & & & & & & & 36.15 & 41.00 & 1.16 & 20.46 & 98.77 \\
\hline \multirow{8}{*}{ Acanthite } & & & & & & & 78.06 & & 15.73 & 6.21 & 100.00 \\
\hline & & & & & & & 78.88 & & 12.71 & 8.41 & 100.00 \\
\hline & 2.99 & & & & & & 84.41 & & 4.14 & 11.45 & 100.00 \\
\hline & & & 1.67 & & & & 79.14 & & 3.54 & 11.30 & 100.00 \\
\hline & 0.94 & & & & & & 82.59 & & 3.27 & 13.21 & 100.00 \\
\hline & & & & & & & 87.41 & & 1.27 & 11.32 & 100.00 \\
\hline & & & 5.97 & & & & 65.70 & & & 7.15 & 100.00 \\
\hline & & & & & & & 77.16 & & & 14.63 & 97.76 \\
\hline \multirow{2}{*}{ Polybasite } & 4.57 & & & & 10.35 & & 43.04 & 23.02 & & 19.02 & 100.00 \\
\hline & & & & & & & 65.77 & 21.70 & & 12.53 & 100.00 \\
\hline \multirow{4}{*}{$\begin{array}{l}\text { Argentopyrite- } \\
\text { lenaite-sternbergite }\end{array}$} & 15.12 & & & & & & 61.76 & & & 23.12 & 100.00 \\
\hline & 9.06 & & & & & & 72.59 & & & 18.15 & 100.00 \\
\hline & 8.20 & & & & & & 72.82 & & & 16.98 & 100.00 \\
\hline & 8.24 & & & & & & 80.63 & & & 11.13 & 100.00 \\
\hline
\end{tabular}


Table 4. Compositions of native gold in the Corrida ores.

\begin{tabular}{cccc}
\hline \multirow{2}{*}{ Mineral } & \multicolumn{2}{c}{ Element Concentrations. wt.\% } & Sum \\
\cline { 2 - 3 } & Ag & Au & \\
\hline & 28.45 & 71.55 & 100.00 \\
& 29.50 & 70.50 & 100.00 \\
& 34.04 & 65.96 & 100.00 \\
Native gold & 38.95 & 61.05 & 100.00 \\
(electrum) & 41.46 & 58.20 & 100.00 \\
& 44.60 & 55.40 & 100.00 \\
& 48.50 & 51.50 & 100.00 \\
& 57.51 & 42.49 & 100.00 \\
& 60.64 & 39.36 & 100.00 \\
& 65.67 & 34.33 & 100.00 \\
& 67.11 & 32.89 & 100.00 \\
\hline
\end{tabular}

Table 5. Compositions of silver halides in the Corrida ores.

\begin{tabular}{cccccccc}
\hline \multirow{2}{*}{ Mineral } & \multicolumn{9}{c}{ Element Concentrations, wt. \% } & \multicolumn{1}{c}{ Sum } \\
\cline { 2 - 7 } & $\mathbf{S}$ & $\mathbf{C l}$ & $\mathbf{B r}$ & $\mathbf{F e}$ & $\mathbf{A u}$ & $\mathbf{A g}$ & \\
\hline \multirow{2}{*}{ Bromargyrite } & & 18.32 & 6.01 & & & 75.68 & 100.00 \\
& & 18.18 & 4.19 & & & 77.63 & 100.00 \\
\hline \multirow{3}{*}{ Chlorargyrite } & 1.22 & 22.76 & & & 77.25 & 100.01 \\
& 0.57 & 21.00 & & & 76.21 & 100.00 \\
& & 18.61 & & & 78.43 & 100.00 \\
Au-chlorargyrite & 5.85 & 9.63 & & 20.95 & 63.57 & 100.00 \\
(or phase mixture) & & 4.51 & & 40.63 & 54.87 & 100.00 \\
\hline
\end{tabular}

Quartz is the most widely spread mineral in lode-veinlet zones. Most narrow veins and veinlets, as well as lode central parts, are usually filled with medium- to finely-grained, sometimes platy, light quartz, often associated with adularia (Quartz Type 1) (Figure 2a,b); finely-grained light-shade quartz with massive and porous structures with impregnated $\mathrm{Pb}$, $\mathrm{Zn}$ and Ag sulphides (Quartz Type 2) (Figure 2c,d). The cementing mass in the aggregates has a brecciated structure; fine "enriched" rhythms of colloform-striped formations, narrow veins and veinlets of massive structure are built from dark, finely-grained, cryptocrystalline, to chalcedonic quartz (Quartz Type 3) (Figure 2e,f), saturated with abundant and even submicroscopic impregnation of ore minerals ( $\mathrm{Au}-\mathrm{Ag}$ sulphoselenides, halides, selenides, and sulphides of silver) (Figures 2 and 3; Tables 2 and 3).

Adularia does not exceed $15 \%$ of lode fill; besides, it is observed in combination with sericite and kaolinite in near-lode metasomatic formations. It is light-crème in colour and is presented by hypidiomorphic aggregates, its position in rhythmically striped aggregates is clearly seen in the structure pattern (Figure 2).

Pyrite and arsenopyrite fill fine impregnations (1-2 $\mu \mathrm{m}$ to $0.2 \mathrm{~mm}$, seldom to $3-5 \mathrm{~mm}$ ) both in lode bodies and in wallrock zones of metasomatic alterations. Joint locations of pyrite and arsenopyrite are observed extremely rarely: they are predominantly located separately. Pyrite is abundant and found in association with all established sulphides (Figures 3 and 4). The signs of pyrite cataclasis and recrystallization are widepsread. Arsenopyrite forms practically no mineral associations and often occurs as disseminated inclusions in fine-grained quartz. The pyrite composition is stoichiometric; in the arsenopyrite composition, Fe grades exceed stoichiometric while As and $\mathrm{S}$ ones are lower: $\mathrm{Fe}_{1.10} \mathrm{As}_{0.95} \mathrm{~S}_{0.95}$ (Table 2). 

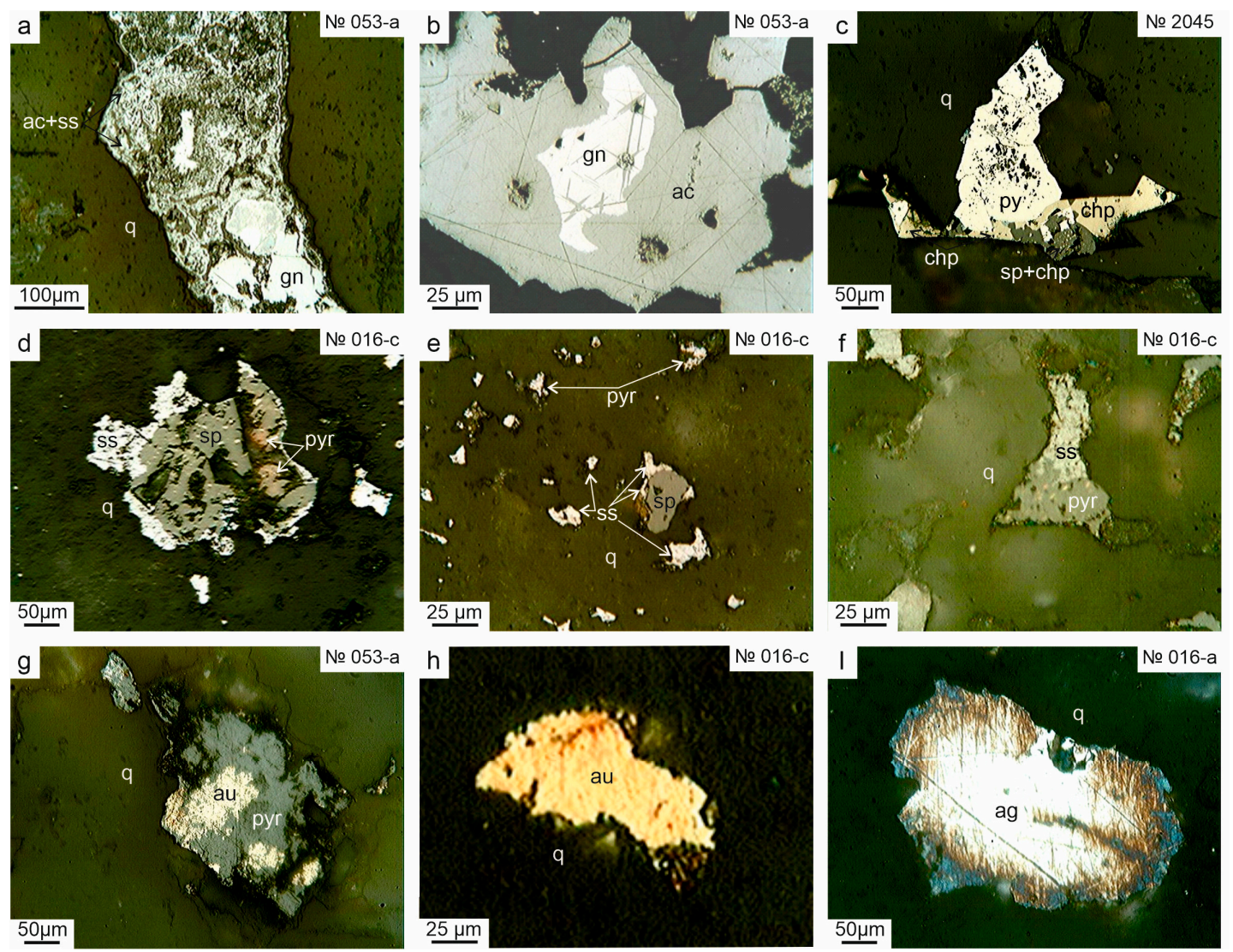

Figure 3. Mineral interrelations at the Corrida deposit: (a)—acanthite grown on galena; (b)—acanthite around galena and acanthite tabular isolations in galena; (c)—assemblage of pyrite, chalcopyrite, and sphalerite impregnated with chalcopyrite emulsion; (d,e)—sphalerite and pyrargyrite with the rim of the mineral mixture of Au-Ag sulphides; (f)—pyrargyrite with the mineral mixture of Au-Ag sulphides; (g)—native gold intergroup with pyrargyrite; (h)_interstitial grain of native gold; (i) —interstitial grain of native silver. Mineral abbreviation in Figures 3 and 4: au-native gold, ag-native silver, fisfischesseritie, uyt—uytenbogaardtite, ac—acanthite, nmt—naumannite, se-argd-Se-bearing argyrodite, pyr-pyrargyrite, an—andorite, chl—chlorargyrite, br—bromargyrite, py—pyrite, apy—arsenopyrite, sp—sphalerite, chp—chalcopyrite, gn—galena, claus—clausthalite, q-quartz, ss-fischesseritie-uytenbogaardtite solid solution.

Sphalerite and chalcopyrite are observed in medium-grained quartz, more seldom in chalcedonic, in the form of uneven impregnation and pockets of up to $1 \mathrm{~mm}$ in size (Figure 3c-e). Sphalerite with fine impregnation of chalcopyrite is episodic (Figure 3c). Sphalerite is often observed with acanthite and naumannite (Figure 4e,f), which grow around and penetrate into it through fractures. Sphalerite $(\mathrm{Zn}, \mathrm{Fe})_{0.99} \mathrm{~S}_{1.01}$ contains up to $6 \mathrm{wt} . \% \mathrm{Fe}$ and up to $4.6 \mathrm{wt} . \% \mathrm{Ag}$ (in half of the grains studied) (Table 2). We suggest that $\mathrm{Ag}$ admixture is related to microscopic or submicroscopic inclusions of discrete Agminerals [48].

Galena is marked in medium-fine-grained light quartz both as fine impregnations and pockets of up to $4-5 \mathrm{~mm}$ in size (Figure $3 \mathrm{a}, \mathrm{b}$ ). In the dark chalcedonic quartz, it is seldom observed in the shape of unevenly distributed submicroscopic grains. Acanthite is often developed on the edges of galena aggregates as well as on their joints. The Seanalog of galena, clausthalite, is found in the paragenesis with naumannite. They occur as submicroscopic impregnations in grey quartz (Figure 4, Table 3,) and in direct proximity to acanthite, pyrite, and sphalerite (Figure 4). 

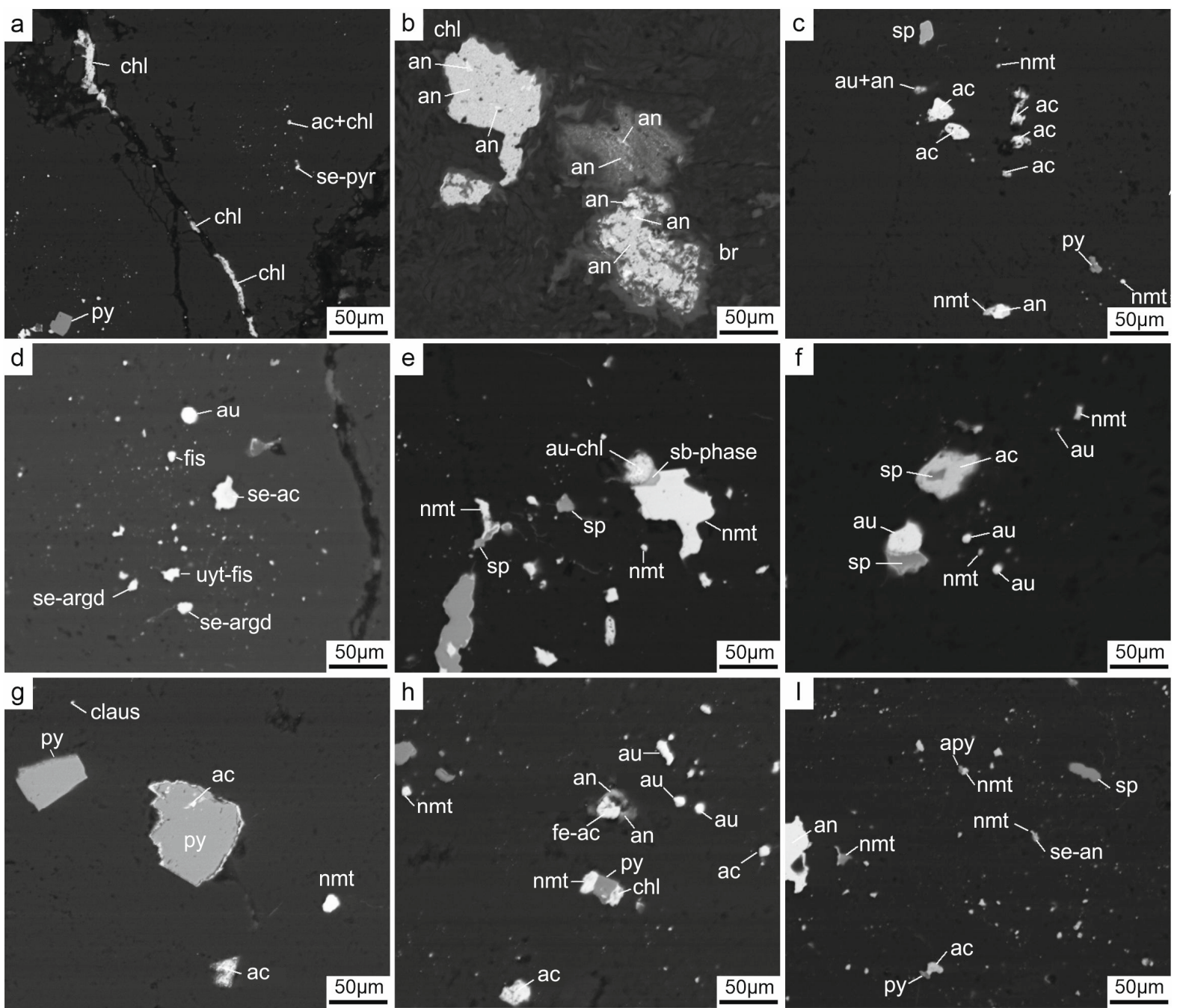

Figure 4. BSE (Backscattered electron) image of microscopic and submicroscopic particles of ore minerals in chalcedonic quartz: (a)—chlorargyrite (chl), acanthite (ac), pyrargyrite (pyr) in fissures; (b)—andorite (an), chlorargyrite (chl) and bromargyrite (br) in relatively large pores filled with anglesite and clay material; (c)—native gold (au), acanthite (ac), naumannite (nmt), sphalerite (sp), pyrite (py) in smaller pores; (d)—acanthite (ac), argyrodite (argd), uytenbogaardtite (uyt) and fischesserite (fis) impregnation; (e,f)—naumannite (nmt), chlorargyrite (chl), sphalerite (sp) and native gold (au) impregnation; (g)—pyrite (py) and acanthite (ac) impregnation; (h)—native gold (au), naumannite (nmt), acanthite (ac) and pyrite (py) in smaller pores; (I) —naumannite (nmt), acanthite (ac) and arsenopyrite (apy) in smaller pores.

In chalcedonic quartz, submicroscopic impregnations (Figure 4, Table 3) consist of clausthalite, naumannite, uytenbogaardtite-fischesserite series, argyrodite, andorite, pyrargyrite, lenaite, and acanthite. There is also polybasite, which is characterized by a lower content of $\mathrm{Ag}$, higher $\mathrm{Cu}$ and Fe contents, and absence of As. Rarely observed mineral mixtures of the argentopyrite-lenaite-sternbergite series are characterized by lower Fe and higher Ag contents (Table 3).

The most common Ag-bearing mineral in ores is acanthite, which occurs in associations with galena (Figure $3 b$ ), naumannite, argyrodite, clausthalite, and jarosite. It has the nonstoichiometric composition, and often contains Se (1.3 to $15.7 \mathrm{wt} . \%$ ) and Fe (up to $3 \mathrm{wt} . \%$ ) (Table 3). Naumannite shows up to 3 wt.\% S.

Native gold commonly occurs as submicroscopic particles in chalcedonic quartz associated with acanthite (Figure 3) and galena; less often it forms larger (up to $0.5 \mathrm{~mm}$ ), xenomorphic insets in medium- and fine-grained quartz (Figure $3 \mathrm{~h}$ ) in association with 
pyrite and sphalerite. The fineness of native gold varies from 330 to $720 \%$ (Table 4), and averages $458 \%$; values are distributed bimodally, with peaks at $300-400 \%$ and $550-600 \%$.

Native silver is rare in association with acanthite and galena. Silver grains in quartz do not exceed $0.7 \mathrm{~mm}$ in size (Figure $3 \mathrm{i}$ ).

Among ore mineralization, various chlorides and bromides of Ag are present as finely dispersed dissemination in chalcedony (Figure 3, Table 5). They are frequently localized in fissures and interstitions, and associated with anglesite (Figure $4 \mathrm{a}, \mathrm{b}, \mathrm{h}$ ) and jarosite.

Mineralogical analysis showed three productive mineral associations in Corrida ores: pyrite-arsenopyrite-sphalerite-chalcopyrite with native gold and acanthite; galena with native gold and $\mathrm{Au}-\mathrm{Ag}$ sulphides and selenides; limonite-anglesite with acanthite, silver chlorides and bromides. Basic Au- and Ag-bearing minerals are native gold (electrum) and, to a lesser extent, minerals of the uytenbogaardtite-fischesserite series, acanthite, and naumannite.

\subsection{Fluid Inclusions}

In quartz samples from ore bodies of the Corrida deposit, 55 individual primary and primary-secondary FI were studied (Table 6). Under the ambient temperature, all FI are two-phase, gas-liquid in their phase composition (Figure 5). They vary in size from 5 to $20 \mu \mathrm{m}$, of which $28 \%$ smaller than $10 \mu \mathrm{m}$. FI are unevenly distributed, both in groups and individually, in the central zones of quartz crystals (Figure 5), are elongated, and, more rarely, round in shape. About 23\% can be referred to FI with a prevailing gas phase (FF lower than 67) (Table 6, Figure 5b). FI with different FF are typically localized in growth zones and can be considered syngenetic (Figure $5 c$ ).

Table 6. Results of microthermometry studies of individual fluid inclusions in the Corrida productive quartz.

\begin{tabular}{|c|c|c|c|c|c|c|c|c|}
\hline \multirow{2}{*}{ Sample } & \multirow{2}{*}{$\mathbf{n}$} & \multicolumn{3}{|c|}{ Experimental Data } & \multicolumn{4}{|c|}{ Calculation Data } \\
\hline & & $\mathrm{T}_{\text {hom., }}{ }^{\circ} \mathrm{C}$ & $\mathrm{T}_{\text {eut., }}{ }^{\circ} \mathrm{C}$ & $\mathrm{T}_{\text {ice.mel., }}{ }^{\circ} \mathrm{C}$ & $\mathrm{FF}, \%$ & $\mathrm{C}$, wt. $\% \mathrm{NaCl}$ eq. & $\mathrm{d}, \mathrm{g} / \mathrm{cm}^{3}$ & P, bar \\
\hline \multirow{8}{*}{$\begin{array}{c}\text { 016c } \\
\text { Quartz } \\
\text { Type } 1\end{array}$} & 3 & $340-320$ & -20 & -1.4 & 75 & 2.41 & 0.63 & 140-108 \\
\hline & 6 & $314-280$ & -25 & $-2--1.8$ & $50-67$ & $3.39-3.06$ & 0.7 & $82-60$ \\
\hline & 7 & $314-292$ & $-26--20$ & $-2.1--1.5$ & $75-83$ & $3.55-2.57$ & 0.75 & $100-72$ \\
\hline & 2 & $290-288$ & & -0.1 & 75 & 0.18 & 0.7 & $70-68$ \\
\hline & 5 & $286-280$ & $-29--23$ & $-2--1.8$ & 80 & $3.39-3.06$ & 0.7 & $66-60$ \\
\hline & 4 & $279-240$ & $-29--25.6$ & $-2--0.1$ & $75-86$ & $3.39-0.18$ & $0.8-0.7$ & $59-27$ \\
\hline & 3 & $240-237$ & - & -0.1 & $50-67$ & 0.18 & 0.8 & 29 \\
\hline & 3 & 235-192 & -25 & -0.1 & $75-80$ & 0.18 & 0.8 & $27-11$ \\
\hline \multirow{4}{*}{$\begin{array}{c}053 \\
\text { Quartz } \\
\text { Type } 2\end{array}$} & 3 & 307 & -28 & -0.1 & 66 & 0.18 & 0.67 & 90 \\
\hline & 3 & 279 & -25 & -0.1 & 75 & 0.18 & 0.73 & 59 \\
\hline & 5 & $233-223$ & -28 & $-0.3--0.1$ & $83-75$ & $0.53-0.18$ & $0.83-0.8$ & $26-21$ \\
\hline & 5 & $182-172$ & $-32--25$ & $-0.3--0.1$ & $85-83$ & $0.53-0.18$ & 0.9 & $8-7$ \\
\hline 1014B & 3 & 205 & -23.8 & -0.1 & 91 & 0.18 & 0.8 & 14 \\
\hline Quartz & 5 & 183-158 & $-27.5--23$ & -0.1 & $88-80$ & 0.18 & $0.9-0.8$ & $9-6$ \\
\hline Type 3 & 1 & 163 & -22 & -0.1 & 67 & 0.18 & 0.9 & 6 \\
\hline
\end{tabular}

$\mathrm{n}$-number of measurements with similar values, united in one group; FF-fluid inclusion fill factor: ratio of voluminous parts of the liquid phase to the gas one.

In 4 out of 8 compositions of FI "gas" phases, Raman-spectroscopy established $\mathrm{CO}_{2}$ with density from 0.05 to $0.19 \mathrm{~g} / \mathrm{cm}^{3}$ (calculated according to [49]), with minor contents of $\mathrm{N}_{2}$ and $\mathrm{CH}_{4}$ (Figure 6) and $\mathrm{CO}_{2} / \mathrm{N}_{2} / \mathrm{CH}_{4}$ ratios from $0.97 / 0 / 0.03$ to $0.92 / 0.07 / 0.01$.

Most FI are homogenized within the temperature range of $163{ }^{\circ} \mathrm{C}$ to $340{ }^{\circ} \mathrm{C}$ (Table 6). FI with predominant gas phase $(\mathrm{FF}=50)$ are homogenized at $237-300{ }^{\circ} \mathrm{C}$ (Table 6), and those with the liquid phase $(\mathrm{FF}=89-92)$, at $158-205^{\circ} \mathrm{C}$. Homogenization temperatures are distributed bimodally, with peaks at $275-300^{\circ} \mathrm{C}$ and $150-175^{\circ} \mathrm{C}$. 

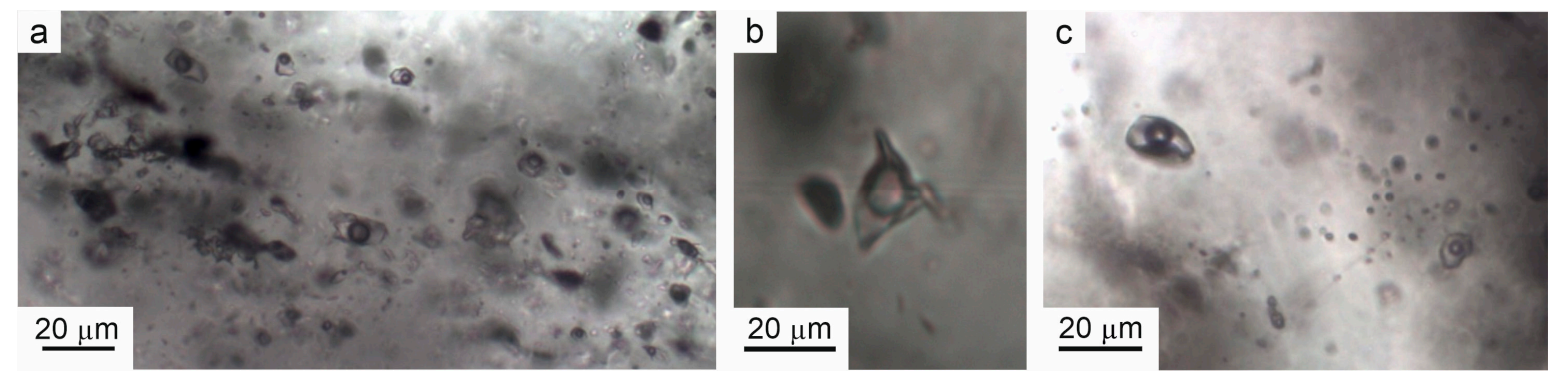

Figure 5. Photomicrographs showing different types of fluid inclusions in the ore-bearing quartz: (a)—fluid inclusions in quartz (sample 053); (b)—fluid inclusion (16C_2fi, see Figure 6), with the gas phase represented by the $\mathrm{CO}_{2}$ mixture not exceeding $0.05 \mathrm{~g} / \mathrm{cm}^{3}$ in density, $\mathrm{N}_{2}$, and $\mathrm{CH}_{4}$ in ratio 0.92/0.07/0.01; (c)—coexistence of two-phase fluid inclusions with different fill factors (sample $016 \mathrm{C}$ ).
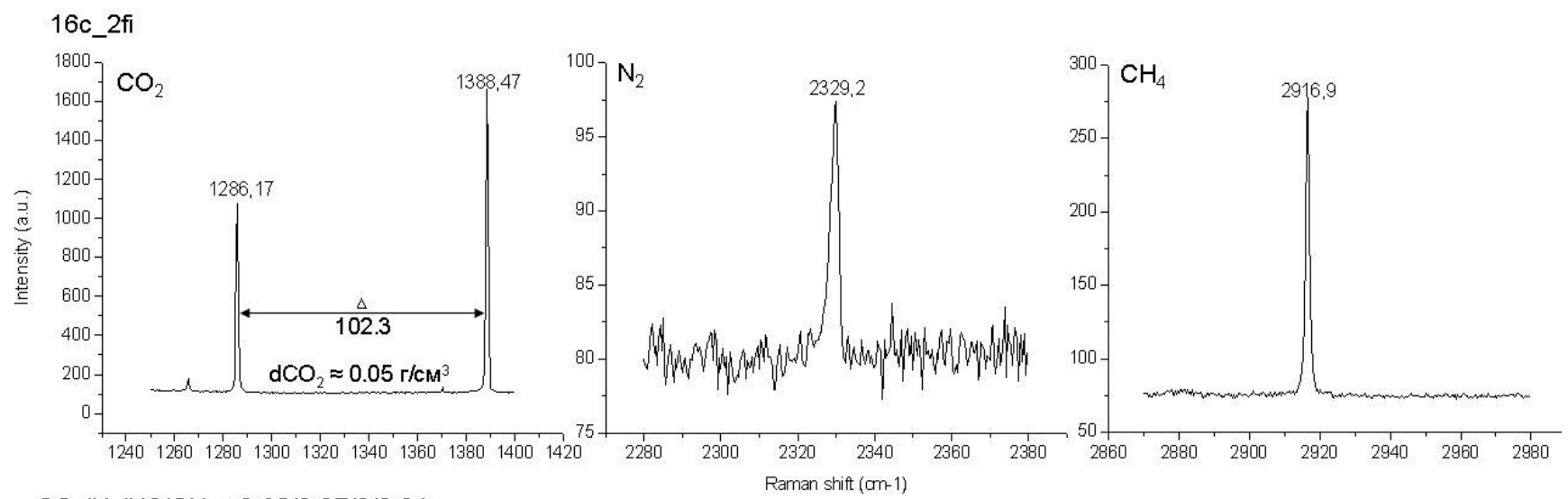

$\mathrm{CO}_{2} / \mathrm{N}_{2} / \mathrm{HS} / \mathrm{CH}_{4}=0.92 / 0.07 / 0 / 0.01$

Figure 6. Raman-spectra, showing the gas composition $\left(\mathrm{CO}_{2}, \mathrm{~N}_{2}, \mathrm{CH}_{4}\right)$ of the fluid inclusion (16c_2fi) in the Corrida ore-bearing quartz.

Cryometric research shows that the last ice crystal in FI melts at temperatures between -2.1 and $-0.1{ }^{\circ} \mathrm{C}$ (Table 6, Figure 7), which corresponds to salt concentration in solutions from 3.55 to $0.18 \mathrm{wt} . \% \mathrm{NaCl}$ eq. FI containing solutions with salt concentration from 3.5 to $2.4 \mathrm{wt} . \% \mathrm{NaCl}$ eq. are homogenized at temperatures from 240 to $340{ }^{\circ} \mathrm{C}$, and form a group on the diagram (Figure 7). FI have the eutectic temperature range of $-32{ }^{\circ} \mathrm{C}$ to $-20^{\circ} \mathrm{C}$, which suggests the presence of $\mathrm{NaCl}$ with $\mathrm{MgCl}_{2}$ and $\mathrm{FeCl}_{2}$ in the solution (Table 6, Figure 7). Salt composition of the solutions from FI remains stable throughout the ore process (Figure 7).

\subsection{Physicochemical Parameters $\left(\mathrm{fO}_{2}, f \mathrm{~S}_{2}, f \mathrm{fe}_{2}, \mathrm{pH}\right)$ of Ore Formation}

Based on the data of mineral compositions of ores and hydrothermal alterations as well as on the results of fluid inclusions study, some physicochemical parameters of mineralization $\left(f \mathrm{~S}_{2}, f \mathrm{Se}_{2}, f \mathrm{O}_{2}\right.$, and $\left.\mathrm{pH}\right)$ have been evaluated.

The presence of pyrite, arsenopyrite, Fe-bearing sphalerite, and native gold in Corrida ores permits one to estimate the range of sulphur and oxygen fugacities. At $300{ }^{\circ} \mathrm{C}$, the pyrite + arsenopyrite $+\mathrm{Ag}_{0.75} \mathrm{Au}_{0.25}+$ acanthite are stable at $\log f \mathrm{~S}_{2}=-11--6$ and $\log f \mathrm{O}_{2}<-26$ (Figure 8a,b, field 1). Absence of the Se-bearing mineralization suggests low values of $f \mathrm{Se}_{2}\left(\log f \mathrm{Se}_{2}<-13\right)$ during ore formation. According to Figure $8 \mathrm{a}, \mathrm{b}$ at $300^{\circ} \mathrm{C}$, the fields of pyrite and native silver do not intersect, which implies lower temperatures of their formation. This association is stable at $200{ }^{\circ} \mathrm{C}$ and $\log f \mathrm{~S}_{2}=-16.5--10.5, \log f \mathrm{Se}_{2}<-18$, and $\log f \mathrm{O}_{2}<-36$ (Figure $8 \mathrm{c}, \mathrm{d}$, field 2). 

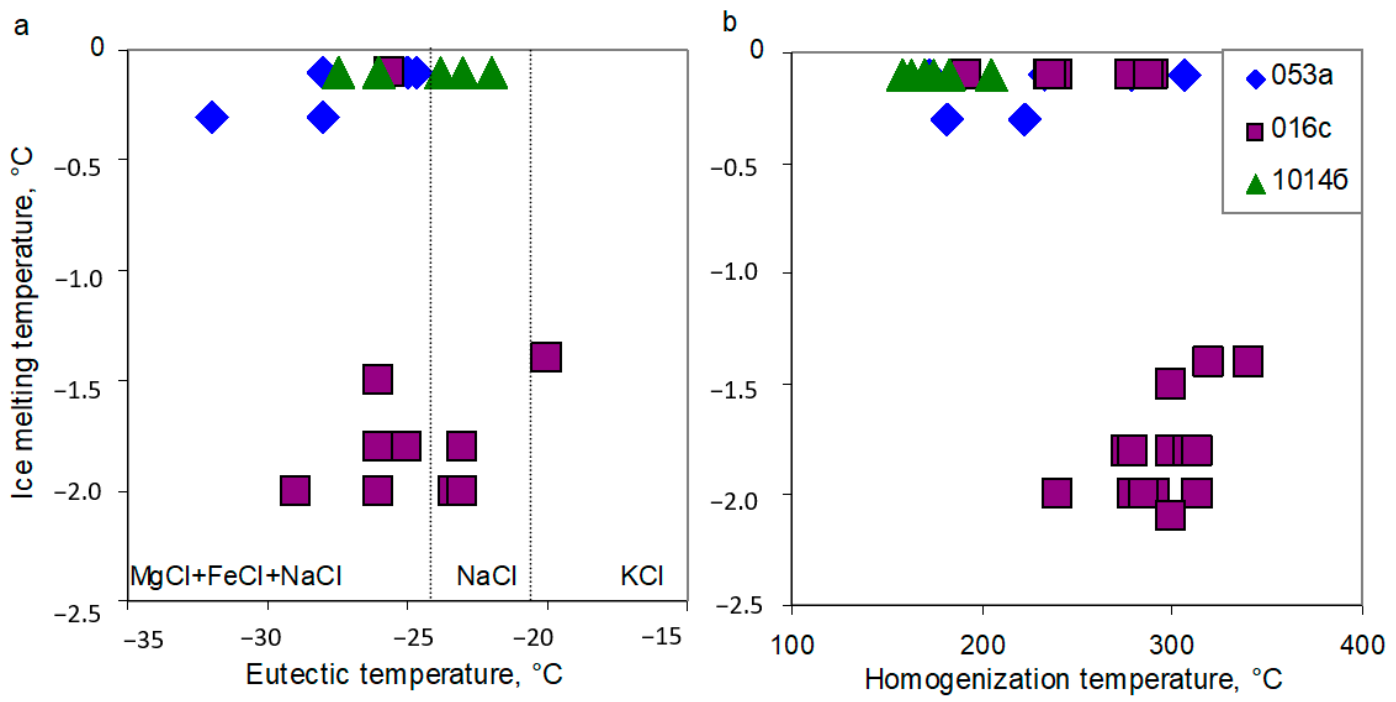

Figure 7. Plots of the last ice crystal melting temperature vs. eutectic temperature (a) and last ice crystal melting temperature vs. homogenization temperature (b), illustrating the distribution patterns of the data points for different types of quartz.

The emergence of Se-containing minerals (Ag sulphoselenides-Se-acanthite, S-naumannite; fischesserite, clausthalite) in the ores testifies to the increasing role of selenium in the mineral formation process. According to the genetic model, at this stage hydrothermal solutions may have boiled. As a result of boiling, porous chalcedony is formed and micromineral phases are deposited in pores with $S$ and Se subliming by the scheme: Se-acanthite S-naumannite + clausthalite + native gold - native silver + chlorargyrite + bromargyrite - uytenbogaardtite + fischesserite. At $100{ }^{\circ} \mathrm{C}$, Se-acanthite with the composition $\mathrm{Ag}_{2} \mathrm{~S}-$ $\mathrm{Ag}_{1.94} \mathrm{~S}_{0.52} \mathrm{Se}_{0.54}$ is formed at $\log f \mathrm{~S}_{2}=-21--16, \log f \mathrm{Se}_{2}=-28--22$ and $\log f \mathrm{O}_{2}<-48$ (Figure 9a,b, field 3); the upper stability limit of $f S_{2}$ corresponds to the line of uytenbogaardtite occurrence. The stability field of naumannite $\left(\mathrm{Ag}_{1.94} \mathrm{~S}_{0.33} \mathrm{Se}_{0.73}-\mathrm{Ag}_{2} \mathrm{Se}\right)$ combined with clausthalite at $100{ }^{\circ} \mathrm{C}$ is limited within the intervals of $\log f S_{2}$ from -25 to $-16, \log f \mathrm{Se}_{2}$ from -26.5 to -21 and $\log f \mathrm{O}_{2}<-48$ (Figure $9 \mathrm{a}, \mathrm{b}$, field 4 ).

The stability field of native silver (Figure 9a,b, field 5) corresponds to the lower values of $\log f S_{2}<-21$ and $\log f \mathrm{Se}_{2}<-27$. The minimum value of $\log f \mathrm{~S}_{2}=-24.6$ was evaluated by the pyrite-pyrrhotite $\left(\mathrm{FeS}_{2} / \mathrm{Fe}_{7} \mathrm{~S}_{8}\right)$ stability line, and the maximum limit for $\log f \mathrm{O}_{2}=-54$, by the line of oxides (hematite, cuprite) and sulphates (anglesite, $\mathrm{Ag}_{2} \mathrm{SO}_{4}$ ) appearance. The association of $\mathrm{Au}_{0.5} \mathrm{Ag}_{0.5}$ with petrovskaite or $\mathrm{Ag}_{0.75} \mathrm{Au}_{0.25}$ with uytenbogaardtite at this temperature is formed at the values of $\log f S_{2}=-13.9$ and -16.3 . The association of $\mathrm{Ag}_{0.75} \mathrm{Au}_{0.25}$ with fischesserite or $\mathrm{Au}_{0.5} \mathrm{Ag}_{0.5}$ with fischesserite or naumannite $\left(\mathrm{Ag}_{0.5} \mathrm{Au}_{0.5}\right.$ $+\mathrm{Ag}_{2} \mathrm{Se} / \mathrm{Ag}_{3} \mathrm{AuSe}_{2}+\mathrm{Au}$ ) is formed at $\log f \mathrm{Se}_{2}=-21.1$ and -18.4 . AuSe is formed at $\log f \mathrm{Se}_{2}<-14$. Minerals of the uytenbogaardtite-fischesserite series below $100{ }^{\circ} \mathrm{C}$ are stable at $\log f \mathrm{~S}_{2}$ from -25 to $-14, \log f \mathrm{Se}_{2}<-14$, and $\log f \mathrm{O}_{2}<-48$ (Figure 9a,b, field 6).

The Corrida ores' mineral composition is peculiar for the presence of Ag chlorides and bromides in the hypergene association with acanthite, jarosite, anglesite, limonite, and chalcocite, which permits evaluation of their stability fields. Below $100{ }^{\circ} \mathrm{C}$, chlorargyrite and bromargyrite are formed at $\log f \mathrm{O}_{2}>-46$ and $\mathrm{pH}<6$; under $25^{\circ} \mathrm{C}$, at $\log f \mathrm{O}_{2}>-60$ and $\mathrm{pH}<9$ (Figure 9c,d); consequently, Ag halides are more stable under lower temperatures. For the hypergene association, critical values of sulphur and selenium fugacity correspond to the stability lines of copper sulphide $\left(\mathrm{Cu}_{2} \mathrm{~S}\right.$, chalcocite) and selenide $\mathrm{Cu}_{2} \mathrm{Se}\left(\log f \mathrm{~S}_{2}\right.$ from -44 to $-20.6, \log f \mathrm{Se}_{2}<-18$ ) (Figure 9a), while oxygen fugacities are limited by the anglesite stability lines $\left(\log f \mathrm{O}_{2}\right.$ from -62 to -50$)$. 

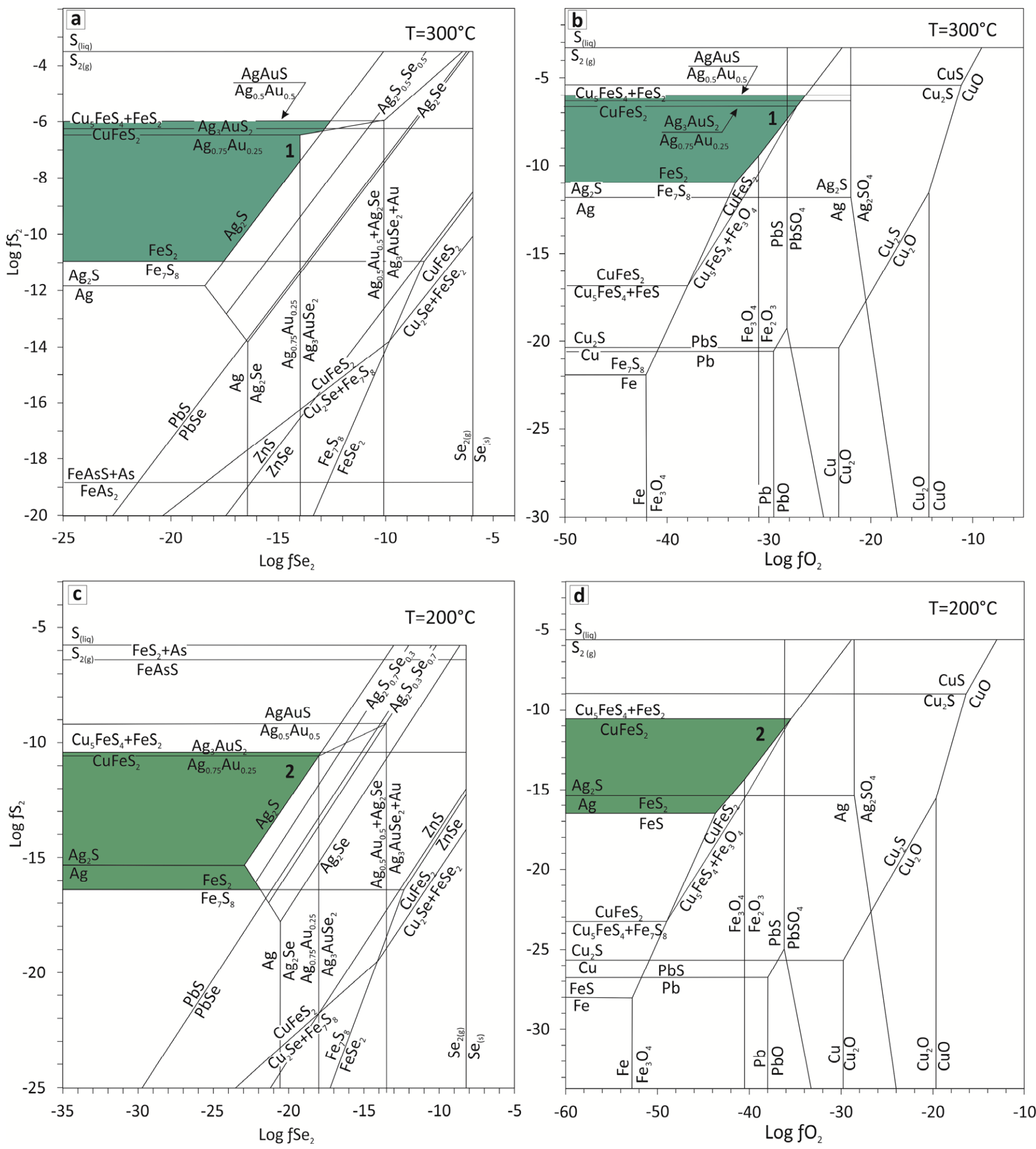

Figure 8. $\quad \log f \mathrm{~S}_{2}-\log f \mathrm{Se}_{2}$ and $\log f \mathrm{~S}_{2}-\log f \mathrm{O}_{2}$ diagrams at $300^{\circ} \mathrm{C}(\mathbf{a}, \mathbf{b})$ and $200{ }^{\circ} \mathrm{C}(\mathbf{c}, \mathbf{d})$ and stability fields of the Corrida mineral associations: field 1-pyrite + arsenopyrite + native gold + acanthite-1; field 2-pyrite + chalcopyrite + acanthite-2 + native silver. 

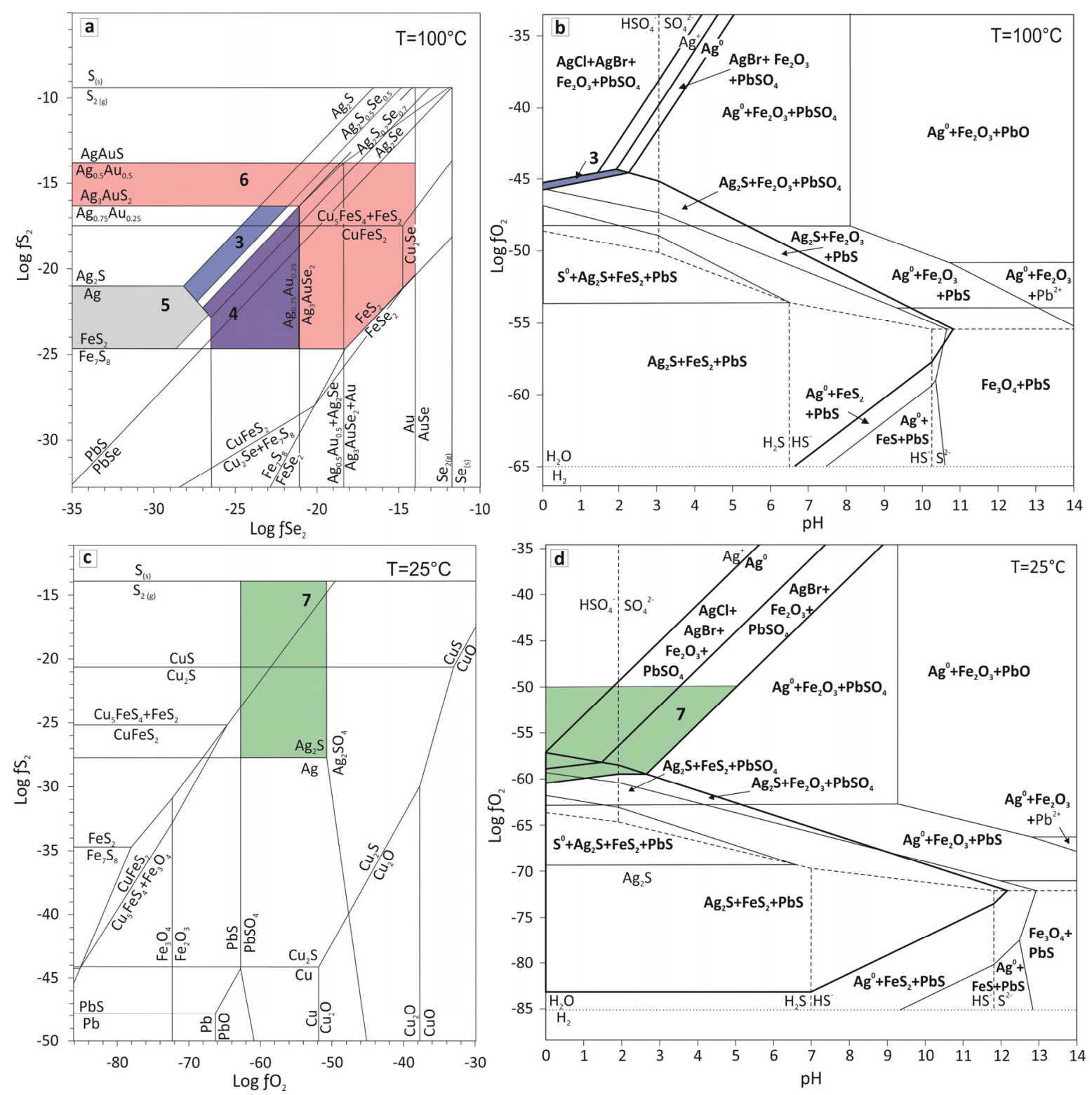

Figure 9. Diagrams of $\log f \mathrm{~S}_{2}-\log f \mathrm{Se}_{2}(\mathbf{a})$ and $\log f \mathrm{O}_{2}-\mathrm{pH}(\mathbf{b})$ at $100{ }^{\circ} \mathrm{C}, \log f \mathrm{~S}_{2}-\log f \mathrm{O}_{2}(\mathbf{c})$ and $\log f \mathrm{O}_{2}-\mathrm{pH}(\mathbf{d})$ at $25{ }^{\circ} \mathrm{C}$, and stability fields of the Corrida mineral associations: field 3-Se-acanthite $\left(\mathrm{Ag}_{2} \mathrm{~S}-\mathrm{Ag}_{1.94} \mathrm{~S}_{0.52} \mathrm{Se}_{0.54}\right)+\mathrm{Ag}$ halides; field 4-S-naumannite $\left(\mathrm{Ag}_{1.94} \mathrm{~S}_{0.33} \mathrm{Se}_{0.73}-\mathrm{Ag}_{2} \mathrm{Se}\right)+$ clausthalite (PbSe); field 5- $\mathrm{Au}-\mathrm{Ag}$ solid solutions; field 6uytenbogaardtite-fischesserite; field 7-acanthite + chlorargyrite + bromargyrite + anglesite $\left(\mathrm{PbSO}_{4}\right)$. Element concentrations used in calculation: $[\mathrm{S}]=10^{-2} \mathrm{M},[\mathrm{Cl}]=10^{-1} \mathrm{M},[\mathrm{Br}]=10^{-2} \mathrm{M},[\mathrm{Ag}]=10^{-7} \mathrm{M}$.

The electrum-sphalerite geothermometer is used for calculating the temperature and $\mathrm{S}$ fugacity values. In the present research, we studied the homogeneous grains of native gold in paragenesis with sphalerite. The composition of native gold from this paragenesis varies within the range $\mathrm{x}_{\mathrm{Ag}}=0.630-0.731$; mole fraction of $\mathrm{FeS}$ in sphalerite $\left(\mathrm{x}_{\mathrm{FeS}}\right)$ is between 0.019 and 0.055 . The calculations show that the formation of this mineral assemblage, with the above-mentioned compositions of native gold and sphalerite, requires temperatures from 192 to $274{ }^{\circ} \mathrm{C}$ and $\log f S_{2}$ from -15.6 to -11.4 . Calculated by different equations [17,47], these characteristics are close in value (Table 7) and do not exceed the above-estimated boundary values of $f S_{2}$. 
Table 7. Estimated values of the mineral formation temperature and sulphur fugacities.

\begin{tabular}{|c|c|c|c|c|c|c|c|c|}
\hline \multirow{2}{*}{ № } & \multirow{2}{*}{$\mathrm{x}_{\mathrm{FeS}}$} & \multirow{2}{*}{$\mathbf{x}_{\mathrm{Ag}}$} & \multirow{2}{*}{$\mathbf{T}^{\circ}, \mathrm{C}[17] /[47]$} & \multirow{2}{*}{$\log f S_{2}[17] /[47]$} & \multirow{2}{*}{ № } & \multirow{2}{*}{$\mathrm{x}_{\mathrm{FeS}}$} & \multicolumn{2}{|c|}{$\log f S_{2}[17] /[47]$} \\
\hline & & & & & & & $175^{\circ} \mathrm{C}$ & $150{ }^{\circ} \mathrm{C}$ \\
\hline \multicolumn{5}{|c|}{ Sphalerite with native gold } & \multicolumn{4}{|c|}{ Sphalerite with Ag-minerals } \\
\hline 1 & 0.022 & 0.731 & 214.9/192.0 & $-14.06 /-15.62$ & 6 & 0.120 & $-18.35 /-17.63$ & $-20.39 /-19.57$ \\
\hline 2 & 0.027 & 0.719 & $223.5 / 201.1$ & $-13.67 /-15.14$ & 7 & 0.094 & $-18.13 /-17.41$ & $-20.17 /-19.35$ \\
\hline 3 & 0.049 & 0.631 & $270.4 / 250.6$ & $-11.53 /-12.60$ & 8 & 0.020 & $-16.79 /-16.07$ & $-18.83 /-18.00$ \\
\hline 4 & 0.055 & 0.630 & $274.2 / 254.6$ & $-11.42 /-12.46$ & 9 & 0.096 & $-18.16 /-17.44$ & $-20.19 /-19.37$ \\
\hline 5 & 0.019 & 0.631 & $237.3 / 216.1$ & $-12.55 /-13.86$ & 10 & 0.089 & $-18.08 /-17.36$ & $-20.12 /-19.30$ \\
\hline
\end{tabular}

In evaluating sulphur fugacity, based on the composition of sphalerite associated with Ag- sulphoselenides and sulphosalts, we used mineral formation temperatures according to the data from the FI research $\left(150-175^{\circ} \mathrm{C}\right)$ that supposedly corresponds to the formation of later Ag-containing minerals. The presence of argentopyrite in the association indicates temperatures below $150{ }^{\circ} \mathrm{C}$ [50]. The mole fraction of FeS in sphalerite $\left(\mathrm{x}_{\mathrm{FeS}}\right)$ in this association varies between 0.020 and 0.120 . Calculations using equations from $[17,47]$ show that sphalerite forms within the range of temperatures from 150 to $175^{\circ} \mathrm{C}$ and sulfur fugacity $\log f S_{2}=-20.4--16.0$, which remains within the $f S_{2}$ boundary values estimated above.

Hydrothermal-metasomatic alterations of Corrida host rocks are represented by hydromica-quartz metasomatites, argillisites, and secondary quartzites replacing them on higher horizons. According to the research on metasomatic rocks [51], weakly acid to near-neutral solutions are typical of argillization, and ultra-acid solutions are typical for secondary quartzites. Moreover, the presence of jarosite in ores at the final stages of Corrida mineralization also suggests participation of acid hydrothermal solutions [52]. At the original stages, mineral-forming solutions might have had weakly acid to near-neutral $\mathrm{pH}$ and were later replaced with acid and ultra-acid solutions.

\section{Discussion}

The research showed three productive mineral associations in the ores of the Corrida deposit: (1) pyrite-arsenopyrite-sphalerite-chalcopyrite with native gold and acanthite; (2) galena with native gold and silver and Au-Ag sulphides and selenides; (3) limoniteanglesite with acanthite and silver chlorides and bromides. A specific feature of the ores is a broad range of Au-Ag-S-Se-Cl-Br minerals. The observed mineral interrelations and bimodal distribution of native gold fineness values imply a two-stage model formation of $\mathrm{Au}-\mathrm{Ag}$ ores at the Corrida deposit: plutogenic-volcanogenic and hypergenic; the first stage can be divided into two substages.

The FI study revealed that the lode body quartz was formed from low-salt (3.55 wt.\% to 0.18 wt.\% $\mathrm{NaCl}$ eq.) hydrotherms, saturated with ions of chlorine, sodium, magnesium, and iron at temperatures from 340 to $158^{\circ} \mathrm{C}$. A low level of salt concentration in hydrothermal solutions is characteristic of epithermal systems. This may be a consequence of the condensation of magmatic vapor [53-55], and the boiling process [56,57]. Most FI were trapped in two temperature intervals, which show that the first ore-forming stage contained two substages: $300-275^{\circ} \mathrm{C}$ and $175-150{ }^{\circ} \mathrm{C}$. It was found that three kinds of quartz filling ore formations were formed successively on cooling of the system: (1) light, medium- to fine-grained quartz (Type 1), building quartz-adularia lode-veinlet aggregates of the colloform-banded and crustified-platy structures (Sample 016c) (Figure 2a,b; Table 5), was formed at 340 to $192{ }^{\circ} \mathrm{C}$; (2) fine-grained quartz (Type 2), forming aggregates of massive, brecciform, and porous structures, with mostly galena mineralization (Sample 053) (Figure 2c,d; Table 5), at 307 to $172{ }^{\circ} \mathrm{C}$; (3) grey, cryptocrystalline (Type 3), which builds dark rhythms of colloform-banded and banded aggregates, serves as the cementing material for breccia formation, and contains submicroscopic impregnations of gold and silver minerals (Sample 1014B) (Figure 2e,f; Table 5), at 205 to $158{ }^{\circ} \mathrm{C}$. In ore-forming 
solutions, trapped by the light quartz FI (Type 1), salt concentration is seven times as large (Table 5; Figure 7) as that in the grey quartz FI (Type 3). Simultaneously, low-density $\mathrm{CO}_{2}$ with minor $\mathrm{N}_{2}$ and $\mathrm{CH}_{4}$ (Figure 6) was found only in the light quartz $\mathrm{FI}$, which means that in the initial period, up to approximately $300{ }^{\circ} \mathrm{C}$, the ore-forming fluid contained low-density gases. Vapor phases, according to [57,58], are capable of transporting gold in the form of colloid particles of heterogeneous trapping. Prokofiev et al. [59] determined the presence of gold as nanoparticles in fluid inclusions by optical and spectroscopic methods. The FI in quartz from the Corrida deposit are very small. We observed no gold as nanoparticles in them. Possible species of gold transport in the ore-forming epithermal system are chloride and hydrosulfide complexes [43,60,61]. Breccia ore formations, cemented by the low-temperature variety of quartz, indicate that the hypogene stage is complicated by tectonic, probably seismic, fluctuations.

Thermodynamic modeling showed that the pyrite-arsenopyrite-argentite (acanthite) assemblage can be formed at $300{ }^{\circ} \mathrm{C}$ with $\log f \mathrm{~S}_{2}$ from -11 to $-6, \log f \mathrm{Se}_{2}$ from -25 to -13 , $\log f \mathrm{O}_{2}$ from -50 to -26 ; pyrite-chalcopyrite-argentite(acanthite) assemblage, at $200{ }^{\circ} \mathrm{C}$ with $\log f S_{2}$ from -16.5 to $-10.5, \log f \mathrm{Se}_{2}$ from -25 to $-15, \log f \mathrm{O}_{2}$ from -50 to -36 ; Se-bearing mineralization, at $100^{\circ} \mathrm{C}$ with $\log f \mathrm{~S}_{2}$ from -16 to $-24.6, \log f \mathrm{Se}_{2}>-28$ and $\log f \mathrm{O}_{2}>-54$. At the same time, chlorargyrite and bromargyrite can be formed at the $\mathrm{pH}<6$ at $100^{\circ} \mathrm{C}$ and $\mathrm{pH}<3$ at $25^{\circ} \mathrm{C}$.

According to experimental research and thermodynamic modeling results [51,52], in the core sample of hydrothermal-metasomatic alterations of host rocks, at the $400-500 \mathrm{~m}$ horizon, hydromica-quartz metasomatites and argillisites are replaced by kaolinite-alunitequartz secondary quartzites and monoquartzites, which indicates the change of $\mathrm{pH}$ in the solutions from weakly acid-near-neutral to acid during mineral formation. The horizon, in which kaolinite-alunite-quartz metasomatism is manifested, presumably corresponds to the level of the Corrida ore system paleo surface, where geothermal processes were accompanied by boiling, solution oxidation, and formation of quartz platy aggregate [62]; these might have even had zero connection with the ore formation process ("overprinting ore") [9].

Thus, it was established that in the Corrida ore system, on the background of lowering temperature, boiling, decreasing fluid salt concentration, and $\mathrm{pH}$ changing from nearneutral to acid, the oxidation potential was increasing, sulphur activity was lowering, but selenium activity was growing. These factors resulted in the significant variation of sulphoselenides and selenides of Ag in ores. According to the results of thermodynamic modeling and experiments $[63,64]$, at such physicochemical conditions, the role of selenium as an ideal precipitator of $\mathrm{Ag}$ is multiplied. Here, the buried waters of an oxygen-free marine paleobasin saturated with an organic matter could be the source of selenium [65]; the waters warmed to over $250^{\circ} \mathrm{C}$, and the biologically bound selenium could mobilize into a hydrothermal fluid [66]. Their deposition in the discussed area was favorably promoted by shallow deposition of the OCVB built by the flinty masses of the Velmay island-arc terrane, less permeable than the OCVB volcanites and, therefore, capable of confining water.

Comparatively high, for epithermal ores, initial temperature of ore-forming fluid, presence of low-density gases and broadly spread acanthite in ores suggest that an intrusion chamber could be the source of the ore-forming fluid [10]. Probably such chamber for the Corrida ore system was a stock built by syenites and monzonites of the Ekityn complex, of the estimated age $84 \pm 1.2 \mathrm{Ma}$ [24], which was formed during the evolution of the central part of the Erguveyem volcano-tectonic structure. The ore process occurred close to this time, which is indicated by hydrothermal-metasomatic alterations in the rocks of the Leurvaam and the Amgen' Formation ( $84-80 \mathrm{Ma}$ ) and complete absence of such alterations in the rocks of the Nunlingran Formation of the Campanian age [22,25]. These data allow one to estimate a possible period of the Corrida formation as 84 to $80 \mathrm{Ma}$ [67], i.e., the time when the basic volume of OCVB acid magmas was formed $[23,68]$. 
The data obtained in the present study (adularia availability, colloform ore structures, development of arsenopyrite and sphalerite, wide range of Au-Ag minerals, absence of enargite, tennantite, tetrahedrite, and other sulfosalts characteristic for HS systems [17]) show near-neutral $\mathrm{pH}$ of ore-forming solutions in the basic part of the system. The presence of $\mathrm{CO}_{2}$ in the ore-forming fluid at the initial stage, as an indicator of redox reactions under interaction of fluid with rocks [18], allows us to classify the Corrida deposit as an LS-type deposit. It was determined, for this group of objects, that the most favorable temperature conditions for the formation of rich ores are $180-280^{\circ} \mathrm{C}$ [9]; temperatures above $280{ }^{\circ} \mathrm{C}$ (in this case, maximum ore formation temperature $340^{\circ} \mathrm{C}$ ) imply a high ore potential of the system.

The Corrida deposit is a new example of epithermal deposits in which $\mathrm{Au}-\mathrm{Ag}$ chalcogenides (acanthite, uytenbogaardtite, fischesserite, naumannite and others) are found in significant quantities [3,7,69-71]. Au-Ag chalcogenides and other gold and silver minerals found in sulfide ores (argyrodite, andorite, pyrargyrite, lenaite, chlorargyrite, bromargyrite) can be of economic importance in the future [72].

\section{Conclusions}

The studied Corrida Au-Ag deposit, located at the periphery of the Erguveyem volcanictectonic depression, belongs to the group of epithermal LS-type deposits. The mineral composition of ore bodies here is characterized by a broad range of Au-Ag-S $\pm \mathrm{Se}-\mathrm{Cl}-\mathrm{Br}$ minerals. Basic Au- and Ag-bearing minerals are native gold and, to a lesser extent, minerals of the uytenbogaardite-fishesserite series, acanthite and naumannite. The ores were formed in two stages. The first hypogenic stage was from 84 to $80 \mathrm{Ma}$. Basic ore mineralization was formed in the medium- to low-temperature environment $\left(340-150{ }^{\circ} \mathrm{C}\right)$ from low-salt (3.55 to $0.18 \mathrm{wt.} \% \mathrm{wt} . \% \mathrm{NaCl}$ eq.) chloride hydrotherms, in the context of fluid boiling, $\mathrm{pH}$ change from near-neutral to acid, decreasing sulfur, and increasing selenium contents. The buried waters of the oxygen-free marine paleobasin saturated with the organic matter could be the source of $\mathrm{Se}, \mathrm{Cl}$ and $\mathrm{Br}$.

Author Contributions: Conceptualization, E.E.K., G.A.P.; methodology, E.E.K., N.E.S., T.V.Z.; validation E.E.K., A.N.G.; formal analysis, E.E.K., N.E.S., T.V.Z.; investigation, E.E.K., N.E.S., T.V.Z., A.N.G.; resources, A.N.G.; writing—original draft preparation, E.E.K., N.E.S., T.V.Z., A.N.G., G.A.P.; writing-review and editing, E.E.K., G.A.P.; project administration, G.A.P. All authors have read and agreed to the published version of the manuscript.

Funding: The studies were carried out by the grant № 13.1902.21.0018 "Fundamental Problems of the Development of the Mineral Resource Base of the High-Tech Industry and Energy in Russia" from the Ministry of Science and Higher Education of the Russian Federation.

Institutional Review Board Statement: The study was conducted according to the guidelines of the Declaration of Helsinki, and approved by the Institutional Review Board (or Ethics Committee) of NEISRI FEB RAS (protocol 1.12.2020).

Informed Consent Statement: Informed consent was obtained from all subjects involved in the study.

Data Availability Statement: Not applicable.

Acknowledgments: The authors thank N. Karmanov (Sobolev Institute of Geology and Mineralogy, Siberian Branch, Russian Academy of Sciences) for help in carrying out work on a scanning electron microscope and an X-ray spectral microanalyzer. We would like to thank the academician N.S. Bortnikov for useful comments in the preparation of this article. We are very grateful to the anonymous reviewers for their comments, which helped to improve the quality of the paper. Appreciation is given to the Academic Editor for careful reading of the manuscript and comments.

Conflicts of Interest: The authors declare no conflict of interest. 


\section{References}

1. Bortnikov, N.S.; Lobanov, K.V.; Volkov, A.V.; Galyamov, A.L.; Vikentev, I.V.; Tarasov, N.N.; Distler, V.V.; Lalomov, A.V.; Aristov, V.V.; Murashov, K.Y.; et al. Strategy metal deposits in the Arctic zone. Geol. Ore Depos. 2015, 57, 479-500. [CrossRef]

2. Volkov, A.V.; Prokofyev, V.Y.; Savva, N.Y.; Sidorov, A.A.; Byankin, M.A.; Uyutnov, K.V.; Kolova, E.E. Ore formation at the Kupol epithermal Au-Ag deposit (Russia's North-East) according to the data from fluid inclusions studies. Geol. Ore Depos. 2012, 54, 295-303. [CrossRef]

3. Savva, N.E.; Pal'yanova, G.A.; Byankin, M.A. The problem of genesis of gold and silver sulfides and selenides in the Kupol deposit (Chukci Peninsula, Russia). Rus. Geol. Geophys. 2012, 53, 457-466. [CrossRef]

4. Savva, N.E.; Kolova, E.E.; Fomina, M.I.; Kurashko, V.V. Gold mineralization in explosive breccia bodies: Mineralogical characterization and genetic aspects (Sentyabrsky NE Deposit, Chukotka Region, Arctic Russia). Arktos 2017, 3, 6. [CrossRef]

5. Kolova, E.E.; Volkov, A.V.; Savva, N.Y.; Prokofyev, V.Y.; Sidorov, A.A. Features of ore formation at the Dvoynoye epithermal Au-Ag deposit (West Chukotka). Dokl. Earth Sci. 2018, 478, 561-565. [CrossRef]

6. Volkov, A.V.; Prokofyev, V.Y.; Sidorov, A.A.; Vinokurov, S.F.; Yelmanov, A.A.; Murashov, K.Y.; Sidorova, N.V. Conditions of the Au-Ag epithermal mineralization formation in the Amguema-Kanchalan volcanic field (East Chukotka). Voclanol. Seismol. 2019, 13, 335-347. [CrossRef]

7. Zhuravkova, T.V.; Palyanova, G.A.; Kalinin, Y.A.; Goryachev, N.A.; Zinina, V.Y.; Zhutova, L.M. Physicochemical conditions of formation of gold and silver paragenesis at the Valunistoe deposit (Chukchi Peninsula). Rus. Geol. Geophys. 2019, 60, 1247-1256.

8. Heald, P.; Hayba, D.O.; Foley, N.K. Comparative anatomy of volcanic-hosted epithermal deposits: Acid sulfate and adulariasericite types. Econ. Geol. 1987, 82, 1-26. [CrossRef]

9. White, N.C.; Hedenquist, J.W. Epithermal environments and styles of mineralization: Variations and their causes, and guidelines for exploration. J. Geochem. Explor. 1990, 36, 445-474. [CrossRef]

10. Hedenquist, J.W.; Lowenstern, J.B. The role of magmas in the formation of hydrothermal ore deposits. Nature 1994, 370, 519-527. [CrossRef]

11. Hedenquist, J.W.; Arribas, A.; Gonzalez-Urien, E. Exploration for epithermal gold deposits. Rev. Econ. Geol. 2000, 13, 245-277.

12. Sillitoe, R.H.; Hedenquist, J.W. Linkages between volcanotectonic settings, ore-fluid compositions, and epithermal precious metal deposits. Spec. Publ. Soc. Econ. Geol. 2003, 10, 315-343.

13. Taylor, B.E. Epithermal Gold Deposits. In Mineral Deposits of Canada: A Synthesis of Major Deposit Types, District Metallogeny, the Evolution of Geological Provinces and Exploration Methods; Goodfellow, W.D., Ed.; Mineral Deposits Division Special Publication; Geological Association of Canada: St. John's, NL, Canada, 2007; Volume 5, pp. 113-139.

14. Volkov, A.V.; Goncharov, V.I.; Sidorov, A.A. Gold and Silver Deposits in Chukotka; Neisri Feb Ras: Magadan, Russia, 2006. (In Russian)

15. Struzhkov, S.F.; Konstantinov, M.M. Gold and Silver Metallogeny in the Okhotsk-Chukotka Volcanogenic Belt; Science World: Moscow, Russia, 2005. (In Russian)

16. White, N.C.; Hedenquist, J.W. Epithermal gold deposits: Styles, characteristics and exploration. SEG Newsl. 1995, $23,9-13$.

17. Barton, P.B., Jr.; Skinner, B.J. Sulfide Mineral Stabilities. In Geochemistry of Hydrothermal Ore Deposits, 2nd ed.; Barnes, H.L., Ed.; Wiley Interscience: New York, NY, USA, 1979; pp. 278-403.

18. Giggenbach, W.F. Isotopic shifts in waters from geothermal and volcanic systems along convergent plate boundaries and their origin. Earth Planet. Sci. Lett. 1992, 113, 495-510. [CrossRef]

19. Rye, R.O. The evolution of magmatic fluids in the epithermal environment; the stable isotope perspective. Econ. Geol. 1993, 88, 733-752. [CrossRef]

20. Mancano, D.P.; Campbell, A.R. Microthermometry of enargite-hosted fluid inclusions from the Lepanto, Philippines, highsulfidation CuAu deposit. Geochim. Cosmochim. Acta 1995, 9, 3909-3916. [CrossRef]

21. Izawa, E.; Urashima, Y.; Ibaraki, K.; Suzuki, R.; Yokoyama, T.; Kawasaki, K.; Taguchi, S. The Hishikari gold deposit: High-grade epithermal veins in Quaternary volcanics of southern Kyushu, Japan. J. Geochem. Explor. 1990, 36, 1-56. [CrossRef]

22. André-Mayer, A.S.; Leroy, A.S.; Bailly, J.L.; Chauvet, A.; Marcoux, E.; Grancea, L.; Rosas, J. Boiling and vertical mineralization zoning: A case study from the Apacheta low-sulfidation epithermal gold-silver deposit, southern Peru. Miner. Depos. 2002, 37, 452-464. [CrossRef]

23. Akinin, V.V.; Miller, E.L. Evolution of lime-alkaline magmas in the Okhotsk-Chukotka volcanic belt. Petrol 2011, 19, 237-277. [CrossRef]

24. Isayeva, Y.P.; Zvizda, T.V.; Ushakova, D.D. State Geological Map of the Russian Federation, Scale 1:1 000 000 (3rd Generation), Ser. Chukotka, Sheet Q-60-Anadyr, Explanatory Note; Vsegei Map Factory: St. Petersburg, Russia, 2016; Available online: ftp:/ /ftp.vsegei.ru/Q-60/Q-60_ObZap.pdf (accessed on 28 October 2020).

25. Sakhno, V.G.; Polin, V.F.; Akinin, V.V.; Sergeev, S.A.; Alenicheva, A.A.; Tikhomirov, P.L.; Moll-Stalcup, E.J. The diachronous formation of the Enmyvaam and Amguema-Kanchalan volcanic fields in the Okhotsk-Chukotka volcanic belt (NE Russia): Evidence from isotopic data. Dokl. Earth Sci. 2010, 434, 365-371. [CrossRef]

26. Ledneva, G.V.; Piis, V.L.; Bazylev, B.A. Upper Triassic siliceous-volcanogenic-terrigenous deposits of the Chukchi Peninsula. Rus. Geol. Geophys. 2016, 57, 1423-1442. [CrossRef] 
27. Akinin, V.V.; Gelman, M.L.; Sedov, B.M.; Amato, J.M.; Miller, E.L.; Toro, J.; Calvert, A.T.; Fantini, R.M.; Wright, J.E.; Natal'in, B.A. Koolen metamorphic complex, NE Russia: Implications for the tectonic evolution of the Bering Strait region. Tectonics 1997, 16, 713-729.

28. Glukhov, A.N.; Kolova, E.E.; Savva, N.Y. Gold-silver mineralization of East Chukotka. In Geology E Mineral Resources of Russia's North-East; Proceedings of the 10th All-Russia Conference with International Participation, Yakutsk, Russia, 8-20 April 2020; Neefu Publishers: Yakutsk, Russia, 2020; pp. 192-195.

29. Redder, E. Fluid Inclusions in Minerals; Nauka: Moscow, Russia, 1987.

30. Van den Kerkhof, A.M.; Hein, U.F. Fluid inclusion petrography. Lithosphere 2001, 55, 27-47. [CrossRef]

31. Borisenko, A.S. Studies of the salt composition of gaseous-fluid inclusions in minerals by cryometry. Rus. Geol. Geophys. 1977, 8, 16-27.

32. Bodnar, R.J.; Vityk, M.O. Interpretation of microterhrmometric data for $\mathrm{H}_{2} \mathrm{O}-\mathrm{NaCl}$ fluid inclusions. In Fluid Inclusions in Minerals: Methods and Applications; Pontignano: Siena, Italy, 1994; pp. 117-130.

33. Brown, P. FLINCOR: A computer program for the reduction and investigation of fluid inclusion data. Am. Mineral. 1989, 74, 1390-1393.

34. Zhang, Y.G.; Frantz, J.D. Determination of the homogenization temperatures and densities of supercritical fluids in the system $\mathrm{NaCl}-\mathrm{KCl}-\mathrm{CaCl}_{2}-\mathrm{H}_{2} \mathrm{O}$ using synthetic fluid inclusions. Chem. Geol. 1987, 64, 335-350. [CrossRef]

35. Garrels, R.M.; Christ, C.L. Solutions, Minerals, and Equilibria; Mir: Moscow, Russia, 1968. (In Russian)

36. Chudnenko, K.V. Thermodynamic Modelling in Geochemistry: Theory, Algorythms, Software, Applications; GEO: Novosibirsk, Russia, 2010. (In Russian)

37. Helgeson, H.C.; Delany, J.M.; Nesbitt, H.W.; Bird, D.K. Summary and critique of the thermodynamic properties of rock-forming minerals. Am. J. Sci. 1978, 278, 1-229.

38. Yokokawa, H. Tables of thermodynamic properties of inorganic compounds. J. Natl. Chem. Lab. Ind. 1988, 305, 27-118.

39. Thermodderm Thermochemical and Mineralogical Tables for Geochemical Modeling. Available online: https://thermoddem. brgm.fr (accessed on 1 July 2020).

40. Perfetti, E.; Pokrovski, G.S.; Ballerat-Busserolles, K.; Majer, V.; Gibert, F. Densities and heat capacities of aqueous arsenious and arsenic acid solutions to $350{ }^{\circ} \mathrm{C}$ and 300 bar, and revised thermodynamic properties of $\mathrm{As}(\mathrm{OH})_{3}{ }^{\circ}(\mathrm{aq}), \mathrm{AsO}(\mathrm{OH})_{3}{ }^{\circ}(\mathrm{aq})$ and iron sulfarsenide minerals. Geochim. Cosmochim. Acta 2008, 72, 713-731. [CrossRef]

41. Pokrovski, G.; Gout, R.; Schott, J.; Zotov, A.; Harrichoury, J.C. Thermodynamic properties and stoichiometry of As(III) hydroxide complexes at hydrothermal conditions. Geochim. Cosmochim. Acta 1996, 60, 737-749. [CrossRef]

42. Tagirov, B.R.; Baranova, N.N.; Zotov, A.V.; Schott, J.; Bannykh, L.N. Experimental determination of the stabilities of Au 2 S(cr) at 25 ${ }^{\circ} \mathrm{C}$ and $\mathrm{Au}(\mathrm{HS})_{2}{ }^{-}$at $25-250{ }^{\circ} \mathrm{C}$. Geochim. Cosmochim. Acta 2006, 70, 3689-3701. [CrossRef]

43. Pal'yanova, G.A. Physicochemical modeling of the coupled behavior of gold and silver in hydrothermal processes: Gold fineness, $\mathrm{Au} / \mathrm{Ag}$ ratios and their possible implications. Chem. Geol. 2008, 255, 399-413. [CrossRef]

44. Pal'yanova, G.A.; Chudnenko, K.V.; Zhuravkova, T.V. Thermodynamic properties of solid solutions in the $\mathrm{Ag}_{2} \mathrm{~S}-\mathrm{Ag}_{2} \mathrm{Se}$ system. Thermochim. Acta 2014, 575, 90-96. [CrossRef]

45. Pankratz, L.B. Thermodynamic Data for Silver Chloride and Silver Bromide; US Bur Mines, Rep. Inv. 7430; US Department of Interior, Bureau of Mines: Washington, DC, USA, 1970.

46. Rycerz, L.; Szymanska-Kolodziej, M.; Kolodziej, P.; Gaune-Escard, M. Thermodynamic properties of AgCl and AgBr. J. Chem. Eng. 2008, 53, 1116-1119. [CrossRef]

47. Scott, S.D.; Barnes, H.L. Sphalerite geothermometry and geobarometry. Econ. Geol. 1971, 66, 653-669. [CrossRef]

48. Cook, N.J.; Ciobanu, C.L.; Pring, A.; Skinner, W.; Shimizu, M.; Danyushevsky, L.; Melcher, F. Trace and minor elements in sphalerite: A LA-ICPMS study. Geochim. Cosmochim. Acta 2009, 73, 4761-4791. [CrossRef]

49. Kawakami, Y.; Yamamoto, J.; Kagi, H. Micro-Raman densimeter for $\mathrm{CO}_{2}$ inclusions in mantle-derived minerals. Appl. Spectrosc. 2003, 57, 1333-1339. [CrossRef]

50. Czamanske, G.K. The stability of argentopyrite and sternbergite. Econ. Geol. 1969, 64, 459-461. [CrossRef]

51. Zharikov, V.A.; Rusinov, V.L. Metasomatism and Metasomatic Rocks; Nauchny Mir: Moscow, Russia, 1998; p. 492. (In Russian)

52. Naboko, S.I. Jarosite deposition from acid sulfate water of the Lower Mendeleyev Spring (Kunashir Isle). Proc. Mineral. Mus. 1959, 10, 164-170. (In Russian)

53. Heinrich, C.A. The physical and chemical evolution of low-salinity magmatic fluids at the porphyry to epithermal transition: A thermodynamic study. Miner. Depos. 2005, 39, 864-889. [CrossRef]

54. Berger, B.R.; Henley, R.W. Magmatic-vapor expansion and the formation of high-sulfidation gold deposits: Structural controls on hydrothermal alteration and ore mineralization. Ore Geol. Rev. 2011, 39, 75-90. [CrossRef]

55. Rottier, B.; Kouzmanov, K.; Casanova, V.; Wälle, M.; Fontboté, L. Cyclic dilution of magmatic metal-rich hypersaline fluids by magmatic low-salinity fluid: A major process generating the giant epithermal polymetallic deposit of Cerro de Pasco, Peru. Econ. Geol. 2018, 113, 825-856. [CrossRef]

56. Wilkinson, J.J. Fluid inclusions in hydrothermal ore deposits. Lithos 2001, 55, 229-272. [CrossRef]

57. Banks, D.A.; Bozkaya, G.; Bozkaya, O. Direct observation and measurement of Au and Ag in epithermal mineralizing fluids. Ore Geol. Rev. 2019, 111, 102955. [CrossRef] 
58. Gartman, A.; Hannington, M.; Jamieson, J.W.; Peterkin, B.; Garbe-Schönberg, D.; Findlay, A.J.; Kwasnitschka, T. Boiling-induced formation of colloidal gold in black smoker hydrothermal fluids. Geology 2018, 46, 39-42. [CrossRef]

59. Prokofiev, V.Y.; Banks, D.A.; Lobanov, K.V.; Selektor, S.L.; Milichko, V.A.; Akinfiev, N.N.; Borovikov, A.A.; Lüders, V.; Chicherov, M.V. Exceptional Concentrations of Gold Nanoparticles in 1,7 Ga Fluid Inclusions From the Kola Superdeep Borehole, Northwest Russia. Sci. Rep. 2020, 10, 1108. [CrossRef]

60. Pokrovski, G.S.; Akinfiev, N.N.; Borisova, A.Y.; Zotov, A.V.; Kouzmanov, K. Gold speciation and transport in geological fluids: Insights from experiments and physical-chemical modelling. Geol. Soc. Lond. Spec. Publ. 2014, 402, 9-70. [CrossRef]

61. Williams-Jones, A.E.; Bowell, R.J.; Migdisov, A.A. Gold in solution. Elements 2009, 5, 281-287. [CrossRef]

62. Simmons, S.F.; Christenson, B.W. Origins of calcite in a boiling geothermal system. Am. J. Sci. 1994, 294, 361-400. [CrossRef]

63. Akinfiev, N.N.; Tagirov, B.R. Selenium impact on silver transportation and sedimentation by hydrothermal solutions: Thermodynamic description of the Ag-Se-S-Cl-OH system. Geol. Ore Depos. 2006, 48, 460-472. [CrossRef]

64. Tagirov, B.R.; Baranova, N.N. On the role of selenium in the silver hydrothermal transportation (by experimental data). Geochem. Int. 2009, 6, 666-672.

65. Stotler, R.L.; Frape, S.K.; Shouakar-Stash, O. An isotopic survey of $\delta^{81} \mathrm{Br}$ and $\delta^{37} \mathrm{Cl}$ of dissolved halides in the Canadian and Fennoscandian shields. Chem. Geol. 2010, 274, 38-55. [CrossRef]

66. Layton-Matthews, D.; Leybourne, M.I.; Peter, J.M.; Scott, S.D.; Cousens, B.; Eglington, B.M. Multiple sources of selenium in ancient seafloor hydrothermal systems: Compositional and $\mathrm{Se}, \mathrm{S}$, and $\mathrm{Pb}$ isotopic evidence from volcanic-hosted and volcanicsediment-hosted massive sulfide deposits of the Finlayson Lake district, Yukon, Canada. Geochim. Cosmochim. Acta 2013, 117, 313-331. [CrossRef]

67. Tikhomirov, P.L.; Glukhov, A.N. On the issue of the age of volcanites within the East Chukotka segment of the OCVB and the associated mineralization. In Cretaceous Systems in Russia and Adjacent Countries: Problems of Stratigraphy and Paleogeography; Proceedings of the 10th All-Russia Meeting, Magadan, Russia, 20-25 September 2020; MAOBTI: Magadan, Russia, 2020; pp. 250-252. (In Russian)

68. Tikhomirov, P.L.; Kalinina, E.A.; Moriguti, T.; Makishima, A.; Kobayashi, K.; Cherepanova, I.Y.; Nakamura, E. The Cretaceous Okhotsk-Chukotka volcanic belt (NE Russia): Geology, geochronology, magma output rates, and implications on the genesis of silicic LIPs. J. Volcanol. Geotherm. Res. 2012, 221, 14-32. [CrossRef]

69. Seryotkin, Y.V.; Pal'yanova, G.A.; Savva, N.E. Sulfur-selenium isomorphous substitution and morphotropic transition in the $\mathrm{Ag}_{3} \mathrm{Au}(\mathrm{Se}, \mathrm{S})_{2}$ series. Rus. Geol. Geophys. 2013, 54, 646-651. [CrossRef]

70. Palyanova, G.A.; Savva, N.E.; Zhuravkova, T.V.; Kolova, E.E. Gold and silver minerals in low-sulfide ores of the Julietta deposit (northeastern Russia). Russ. Geol. Geophys. 2016, 57, 1171-1190. [CrossRef]

71. Sidorov, E.G.; Borovikov, A.A.; Tolstykh, N.D.; Bukhanova, D.S.; Palyanova, G.A.; Chubarov, V.M. Gold Mineralization at the Maletoyvayam Deposit (Koryak Highland, Russia) and Physicochemical Conditions of Its Formation. Minerals 2020, 10, 1093. [CrossRef]

72. Palyanova, G.A. Gold and Silver Minerals in Sulfide Ore. Geol. Ore Depos. 2020, 62, 383-406. [CrossRef] 